\title{
Solid State Sensors for Hydrogen Peroxide Detection
}

\author{
Vinay Patel ${ }^{1}\left(\mathbb{D}\right.$, Peter Kruse $^{2}(\mathbb{D})$ and Ponnambalam Ravi Selvaganapathy $1,3, *$ (D) \\ 1 School of Biomedical Engineering, McMaster University, Hamilton, ON L8S 4K1, Canada; \\ patelv77@mcmaster.ca \\ 2 Department of Chemistry and Chemical Biology, McMaster University, Hamilton, ON L8S 4M1, Canada; \\ pkruse@mcmaster.ca \\ 3 Department of Mechanical Engineering, McMaster University, Hamilton, ON L8S 4K1, Canada \\ * Correspondence: selvaga@mcmaster.ca
}

check for

updates

Citation: Patel, V.; Kruse, P.; Selvaganapathy, P.R. Solid State Sensors for Hydrogen Peroxide Detection. Biosensors 2021, 11, 9. https://doi.org/10.3390/bios11010 009

Received: 19 November 2020 Accepted: 22 December 2020 Published: 25 December 2020

Publisher's Note: MDPI stays neutral with regard to jurisdictional clai$\mathrm{ms}$ in published maps and institutional affiliations.

Copyright: $(\odot 2020$ by the authors. Licensee MDPI, Basel, Switzerland. This article is an open access article distributed under the terms and conditions of the Creative Commons Attribution (CC BY) license (https:// creativecommons.org/licenses/by/ $4.0 /)$.

\begin{abstract}
Hydrogen peroxide $\left(\mathrm{H}_{2} \mathrm{O}_{2}\right)$ is a key molecule in numerous physiological, industrial, and environmental processes. $\mathrm{H}_{2} \mathrm{O}_{2}$ is monitored using various methods like colorimetry, luminescence, fluorescence, and electrochemical methods. Here, we aim to provide a comprehensive review of solid state sensors to monitor $\mathrm{H}_{2} \mathrm{O}_{2}$. The review covers three categories of sensors: chemiresistive, conductometric, and field effect transistors. A brief description of the sensing mechanisms of these sensors has been provided. All three sensor types are evaluated based on the sensing parameters like sensitivity, limit of detection, measuring range and response time. We highlight those sensors which have advanced the field by using innovative materials or sensor fabrication techniques. Finally, we discuss the limitations of current solid state sensors and the future directions for research and development in this exciting area.
\end{abstract}

Keywords: solid state sensors; field effect transistor; chemiresisitive sensor; conductometric sensor; hydrogen peroxide; biosensor and sensors

\section{Introduction}

$\mathrm{H}_{2} \mathrm{O}_{2}$ plays an important role in various applications such as medical diagnostics, clinical research, and industrial sectors like food processing, paper, textile, pharmaceuticals as well as cleaning and disinfection products (Figure 1) [1]. $\mathrm{H}_{2} \mathrm{O}_{2}$ is also important physiologically and is involved in metabolic activities, apoptosis, and immune cell activation [2,3]. It plays an important role as an oxidative stress marker, defense agent, and aging [2,4]. It is a crucial biomarker in monitoring various diseases and disorders including diabetes [5], cancer [6], Parkinson's [7], cardiovascular, Alzheimer's [7], and neurodegenerative disorders $[7,8]$. Moreover, $\mathrm{H}_{2} \mathrm{O}_{2}$ is the intermediate molecule formed in reactions involving numerous oxidases such as glucose oxidase, alcohol oxidase, cholesterol oxidase, lactate oxidase, and glutamate oxidase [9]. Further, $\mathrm{H}_{2} \mathrm{O}_{2}$ is used for sterilizing various medical equipment and residual $\mathrm{H}_{2} \mathrm{O}_{2}$ levels need to be monitored to ensure that the equipment is safe to use [10].

$\mathrm{H}_{2} \mathrm{O}_{2}$ measurement and quantification is performed in a variety of sample matrices including environmental samples like water and soil, human fluids like sweat, blood, cell and tissue cultures. $\mathrm{H}_{2} \mathrm{O}_{2}$ is measured using diverse range of methods such as optical [11,12] including colorimetry, chemiluminescence, and fluorescence; and electrochemical [13-16] including potentiometry, voltammetry and amperometry (Figure 1). Optical techniques are limited by high cost, complex testing processes, the requirement of sophisticated and bulky instrumentation, need for trained personnel to operate, and interference from sample matrices. On the other hand, electrochemical sensors offer low-cost, simple instrumentation and fast detection [13]. Nevertheless, electrochemical sensors also suffer from a few limitations such as the requirement for a reference electrode, larger working area, etc. The potentiometric method requires a reference electrode for reliable potential measurement 
while amperometric sensors require a reference electrode to apply a reliable potential bias for the measurement. For potentiometric sensors, a stable response strongly depends on the stability of the reference electrode. However, a miniaturized solid-state reference electrode with long term stability is yet to be realized [17]. For amperometric sensors, a high working electrode potential results in increased interference from interfering molecules [18].

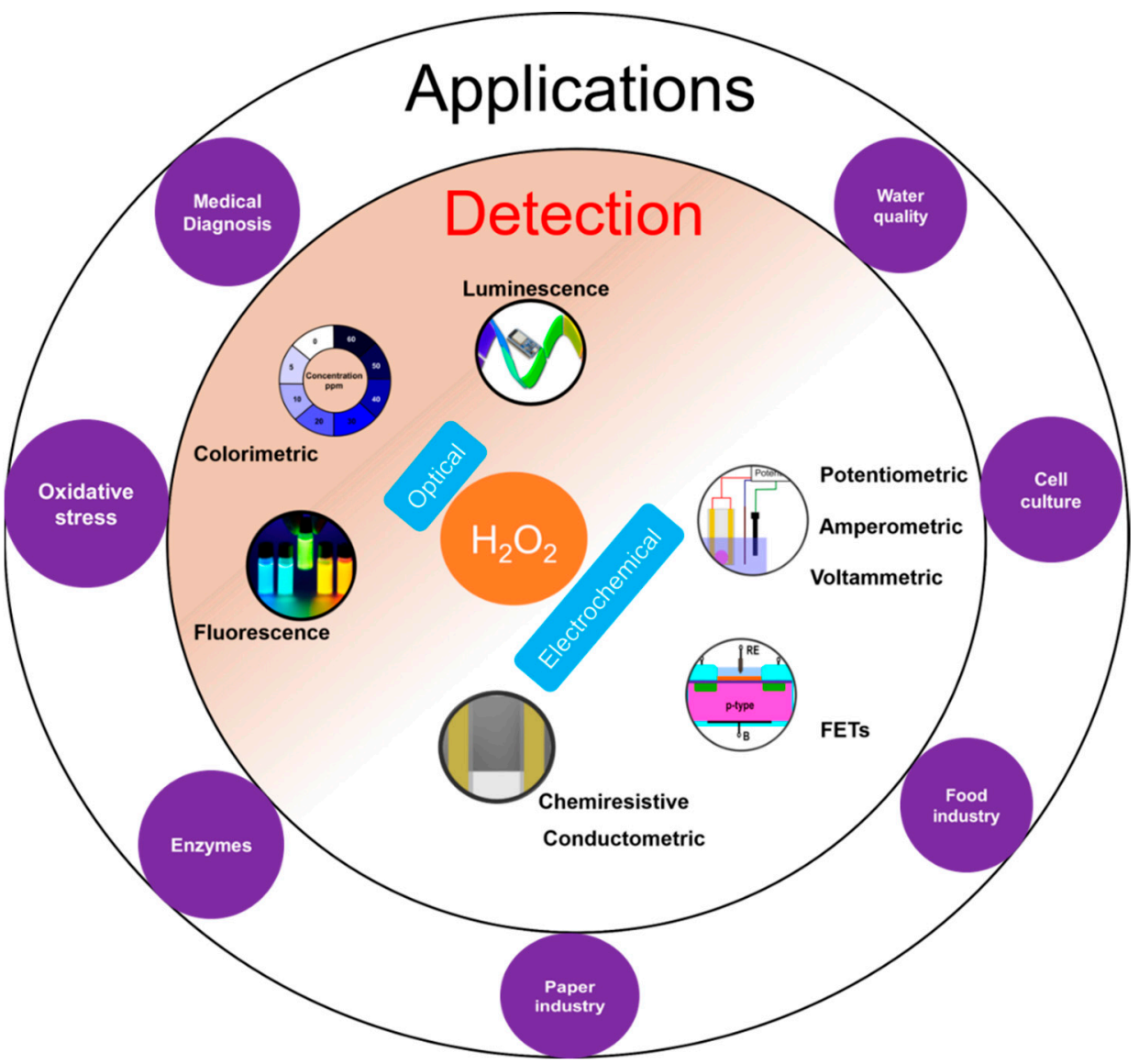

Figure 1. Overview of $\mathrm{H}_{2} \mathrm{O}_{2}$ detection with inner circle containing the two common detection principles: optical and electrochemical; and outer circle with few applications areas of $\mathrm{H}_{2} \mathrm{O}_{2}$ detection.

More recently, solid-state sensors such as chemiresistors [19-21], conductometric sensors [21-23] and field effect transistors (FET) [24-26] have been used to measure $\mathrm{H}_{2} \mathrm{O}_{2}$ while avoiding the aforementioned challenges. Chemiresistors consist of a single sensing layer which measures the change in analyte concentration through alteration in resistance of the layer using two contact electrodes. A small potential bias is applied to the substrate film and the change in current is measured. Advantages of chemiresistors are: high sensitivity, because the resistance changes can occur due to modification at any position of the network unlike techniques like colorimetric which is based on volume modifications; ease of fabrication of sensor arrays due to simple sensor structure; suitability for miniaturization; simple instrumentation setup for measurement and elimination of the need for reference electrodes unlike electrochemical methods [27]. FET based solid state sensors are attractive due to their ability to detect analytes with ultrahigh sensitivity. In addition, FETs can be manufactured easily using the established manufacturing process for metal oxide semiconductor FETs (MOSFET) [9].

Previous reviews on sensors for $\mathrm{H}_{2} \mathrm{O}_{2}$ detection have typically focused on electrochemical and colorimetric sensors. Several papers have been published on enzymatic $[1,13,14,16,28,29]$ and non-enzymatic sensing $[1,15,30,31]$ using those principles and the readers are referred to them for an in-depth analysis in these areas. An in-depth review of the emerging class of solid state $\mathrm{H}_{2} \mathrm{O}_{2}$ sensors is not currently available. This review is focused exclusively 
on chemiresistive, conductometric and FET based $\mathrm{H}_{2} \mathrm{O}_{2}$ sensors which have significant potential for field deployment. A critical analysis of the sensing methods with emphasis on the sensing mechanisms and important parameters like measuring range, limit of detection (LOD), and response time have been provided. The diverse range of functional materials used for sensing and to fabricate these sensors have also been discussed. This review is expected to provide a broad overview of solid state sensors, their suitability for peroxide sensing, and their applications.

\section{Sensing Mechanism}

\subsection{Chemiresistive Sensors}

Chemiresistive sensors are a group of sensors which transduces the chemical changes to resistance change. The sensor response is attributed to surface reactions or adsorption of analyte molecules on the sensing film [32]. This type of sensor was originally developed for gas sensing by monitoring resistance changes with adsorption of gas molecules on the sensor surfaces [32,33]. Typically, a sensor is placed under a small potential bias and the change in current is measured as output and converted into a change in resistance. A general chemiresistor consists of four components: the sensitive or active thin film substrate, contact electrodes, passivation layer and substrate (Figure 2a,b). Although for gas sensing, the contacts may be exposed to the environment, they are typically covered with an insulating film to avoid electrical shorting, especially when used in conducting liquids. The equivalent electrical circuit for a chemiresistive sensor can be represented as shown in Figure 2c, where both contacts are represented by parallel RC circuit depicting both Faradaic and non-Faradaic processes. The sensing layer which remains in contact with the solution is divided into three parallel RC circuits representing surface, bulk, and interface processes. When chemiresistive sensors are operated in DC mode, all capacitance can be neglected from the equivalent circuit (Figure 2c).

(a)

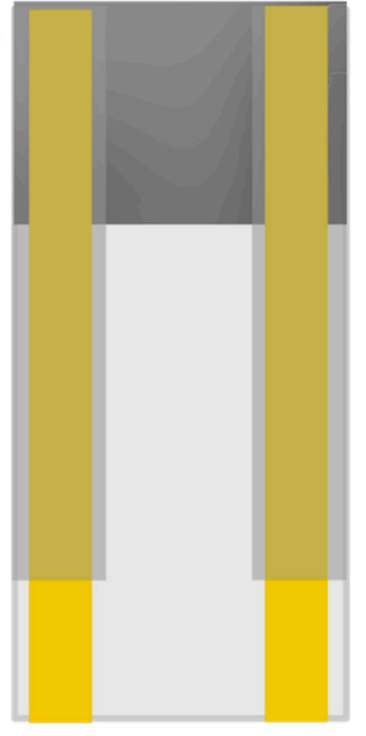

\section{Connectors}

\section{(1)}

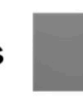

\section{Electrode/active material}
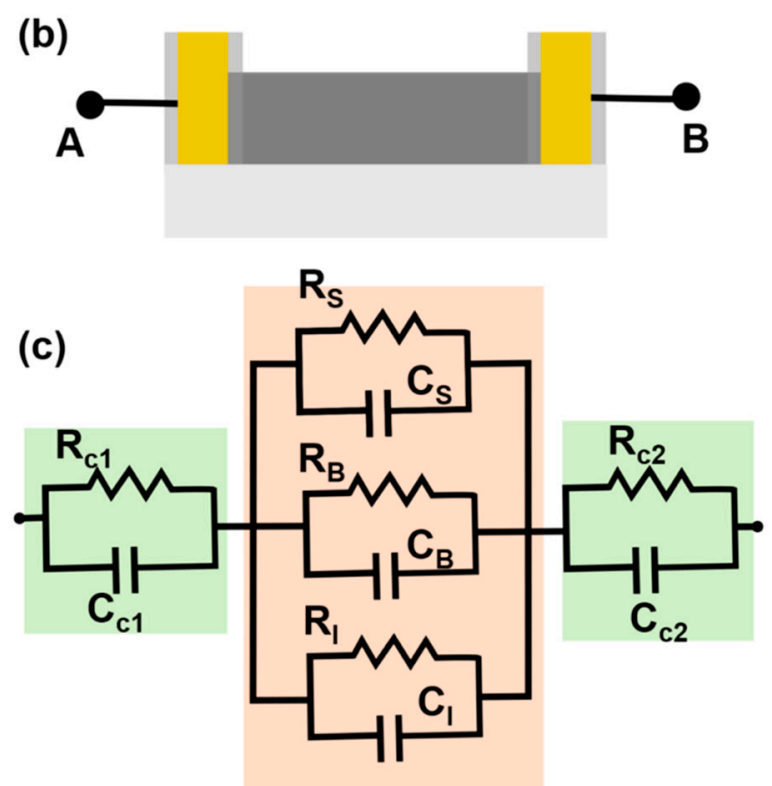

(c)

Figure 2. (a) Top view of a chemiresistive sensor with 4 main components: active material (dark grey), connectors or contacts (gold), dielectric to insulate the contacts (grey) and substrate (light grey) (b) A transverse section of a chemiresistive sensor with two connecting outputs (c) An electrical circuit analog for the chemiresistive sensor with $\mathrm{R}_{\mathrm{c} 1}$ and $\mathrm{R}_{\mathrm{c} 2}$, the contact resistance for the first and second contacts, while $R_{S}, R_{B}$ and $R_{I}$ are the solution, bulk and interfacial resistance. Similar to resistance, capacitance of all the surfaces are labelled accordingly. 
During measurement, the sensor is exposed to the analyte, and adsorption of analyte to the active thin film results in a change in resistance. For instance, carbon nanotubes (CNTs) are generally p-doped when the films are coated using water based CNT dispersions and if analyte adsorption results in the release of electrons, the hole concentration in the active surface is reduced, which results in a decrease in resistance [34]. On the other hand, if the analyte extracts electrons from the CNT film, this will lead to an increase in dominant carriers resulting in an increase in conductivity. Further, this change in resistance due to analyte interactions can occur from factors like increasing the CNT-CNT junction resistance modulation of the Schottky barrier at the CNT-metal contact junction and charge transfer between analyte and CNT. These processes have been described in detail in other reviews $[35,36]$. These sensors have some limitations such as irreversible changes introduced onto the substrate due to application of a potential bias, a high dependence of the sensitivity of the sensor on the substrate thickness, and high contact resistance which can further reduce the sensitivity of the sensor. For instance, in the case when conducting polymers are used as the functional sensing layer, the potential bias can induce an irreversible change in the polymer film resulting in a change to the baseline resistance of the sensor. The analyte can also cause irreversible changes to the sensors surface [19]. Thinner films generally have higher sensitivity as compared to thicker films [33]. For two point measurements, the resistance change has two components: change due to the analyte binding and change in contact resistance between the substrate and the metal contacts [37].

\subsection{Conductometric Sensors}

Conductometric sensors are devices which detect the change in conductivity of the analyte solution due to consumption or generation of ions due to chemical reactions using two conducting electrodes [38]. This method was originally developed to study chemical kinetics of reactions and later exploited by researchers to detect enzyme catalyzed reactions. Conductometric measurements are non-specific as conductivity changes can occur due to the migration of all ions present in the solution. This non-specificity is circumvented by coating enzyme on top of the electrode and doing the measurements in a defined measuring cell. Conventionally, the conductivity measurements are performed in AC mode. Unlike chemiresistive sensors, these sensors offer information through the frequency of the measurement, an important experimental variable to determine non-Faradaic processes. An alternating bias has several advantages such as minimized contact polarization, double layer charging and electrode polarization [39].

Typically, conductometric measurements are done using a pair of identical electrodes (generally interdigitated electrodes) dipped in a solution container with a constant volume. One of the interdigitated electrodes (IDE-1) is coated with the enzyme film and the other does not have any enzyme layer (IDE-2) (Figure 3a). The IDE-2 determines the base conductivity response from other ions and molecules present in the solution. The measurement of both the sensors are done with respect to a counter and/or reference electrode (Figure 3b). The final sensor response is determined by subtracting the signal of IDE- 1 from the signal of IDE-2. Here, the impedance is measured perpendicular to the electrode surface. The equivalent circuit of the electrochemical cell is shown in Figure $3 c$ where $R_{c t 1}$ and $R_{c t 2}$ are the charge transfer resistances for IDE and CE respectively, $\mathrm{W}$ is the Warburg impedance for the IDE which models the diffusional resistance due to both interfaces, $C_{\mathrm{d} 11}$ and $C_{\mathrm{dl} 2}$ are double layer capacitances of IDE and CE respectively and $R_{S}$ is the solution resistance. Enzymatic conductometric sensors are versatile sensors which are low-cost, need a smaller potential bias and require simple instrumentation to generate reliable signals. However, the sensing signal can be affected by temperature variations [39] and changes in the ionic strength of the solution. 
(a)

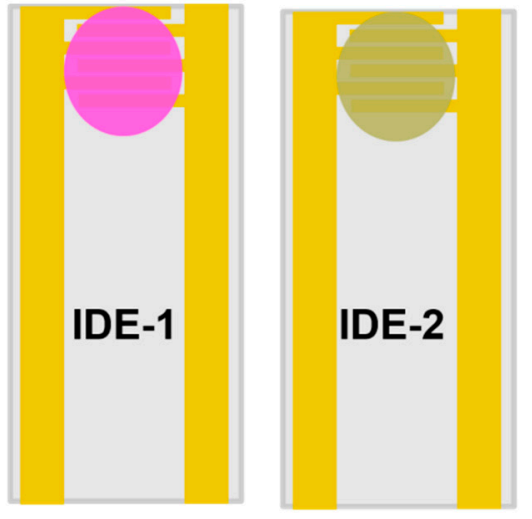

(c)

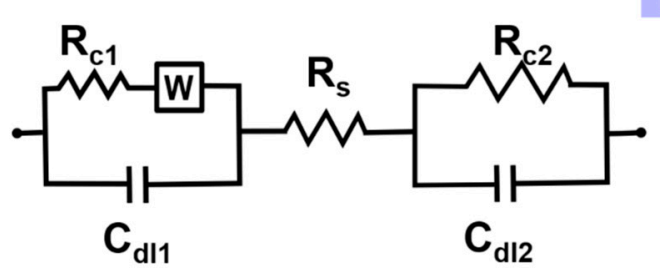

(b)

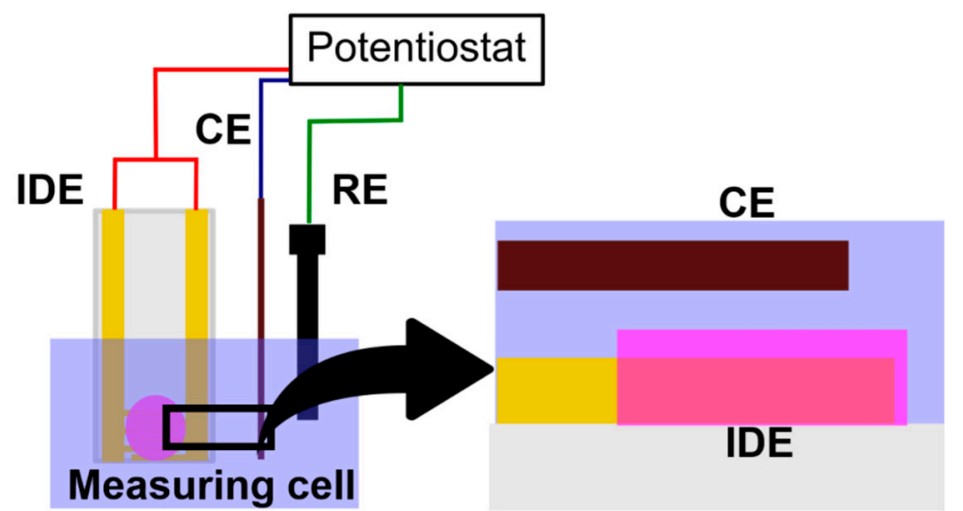

Figure 3. (a) A pair of interdigitated electrodes (IDE): IDE-1 represents the active membrane coated electrode and IDE-2 is the electrode coated with membrane without any active material (b) A schematic representing the experimental setup of a conductometric sensor with IDE, a counter electrode and a reference electrode. The zoomed in picture shows a transverse section of IDE and counter electrode (c) An equivalent circuit for the conductometric sensor with $\mathrm{R}_{\mathrm{C} 1}, \mathrm{~W}$ and $\mathrm{C}_{\mathrm{d} 11}$ representing the charge transfer resistance, Warburg impedance and double layer capacitance, respectively for the IDE; $\mathrm{R}_{\mathrm{S}}$ is the solution resistance; and $\mathrm{R}_{\mathrm{C} 2}$ and $\mathrm{C}_{\mathrm{d} 12}$ representing the charge transfer resistance and double layer capacitance for the counter electrode respectively.

\subsection{FET}

Metal oxide field effect transistors (MOSFETs) are used in electronic circuits as switches, gates, amplifiers etc. MOSFETs can be three or four terminals depending on the presence or absence of back gate (base substrate): source, drain, gate and base substrate. Insulated gate FET (IGFET) is the most common type of MOSFET used currently for chemical sensing. The gate terminal of the IGFET is insulated using a dielectric layer $\left(\right.$ like $\left.\mathrm{SiO}_{2}\right)$. A typical n-channel FET is constructed using a p-type substrate with heavily doped n-type source and drain (Figure 4a). The operation of the FET depends on the potential bias applied to the gate. Under zero bias, the FET channel is non-conducting. For n-channel FET, the conduction begins after a critical threshold potential is applied to the gate. This threshold potential will induce an inversion layer.

Early $\mathrm{H}_{2} \mathrm{O}_{2}$ (and glucose) FET sensors had $\mathrm{pH}$ sensitive material coated on the gate insulator that made it sensitive to changes in local $\mathrm{pH}$ due to generation or consumption of hydrogen ions by an enzyme that catalyzes $\mathrm{H}_{2} \mathrm{O}_{2}$ (Reaction 1) [40-42]. In this reaction, the reduction of $\mathrm{H}_{2} \mathrm{O}_{2}$ was catalyzed in presence of horseradish peroxidase (HRP), with the iodide ion acting as a reducing agent [43].

$$
\mathrm{H}_{2} \mathrm{O}_{2}+2 \mathrm{I}^{-}+2 \mathrm{H}^{+} \stackrel{\mathrm{HRP}}{\rightarrow} \mathrm{I}_{2}+2 \mathrm{H}_{2} \mathrm{O}
$$

In such FETs, the gate dielectric is converted into a hydrogen sensitive film which can generate similar potential change in presence of the analyte (Figure $4 \mathrm{~b}$ ). Then the channel conduction can be influenced by changes in the hydrogen ion concentration. These devices are known as ion selective FETs (ISFETs). Similar to MOSFETs, ISFETs can also be n-channel or p-channel ISFET depending on the doping of the silicon substrate used to fabricate the FET. The drain current depends on the resistance of inversion layer and, 
the potential applied between source and drain. Mathematically, the drain current $\left(I_{d}\right)$ of ISFET is given by [9]:

$$
I_{d}=\mu C_{i}\left(\frac{W}{L}\right) V_{d}\left[V_{g}-\left(E_{r e f}-\phi+\chi_{s o l}-\left(\frac{\phi_{S i}}{q}\right)-\frac{Q_{i}+Q_{s s}}{C_{i}}-\left(\frac{Q_{b}}{C_{i}}\right)+2 \phi_{f}\right)-0.5 V_{d s}\right]
$$

where $\mu$ is mobility of electrons in the channel; $L$ and $W$ are length and width of the channel, respectively; $q$ is the elementary charge, $Q_{b}, Q_{i}, Q_{s s}$ are the charges located in depletion region, insulator region, and surface and interface states, respectively, $\chi_{\text {sol }}$ is solution's surface dipole potential, $E_{r e f}$ is the reference electrode's potential, $\phi_{S i}$ is the electron work function of silicon, $\phi_{f}$ is the potential difference between Fermi level of doped and intrinsic silicon, $V_{d s}$ is the potential applied to the drain with respect to source, $V_{d}$ is the drain potential, $V_{g}$ is gate potential, $C_{i}$ is the capacitance value of the gate, and $\phi$ is the potential of membrane-electrolyte interface.

(a)

(c)
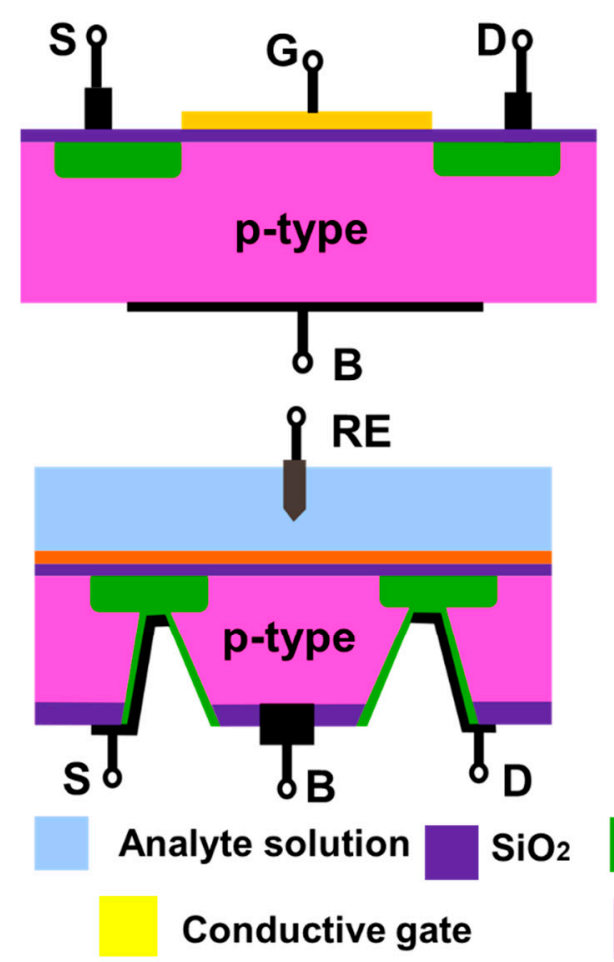

(b)

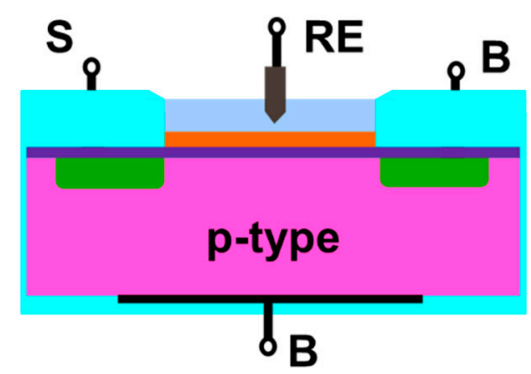

(d)

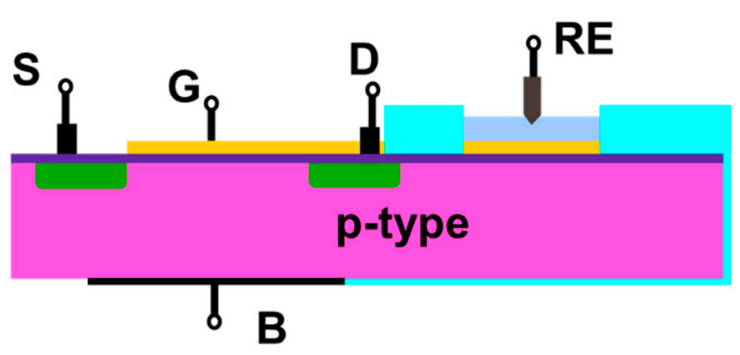

n-doped region $\quad \mathrm{pH}$ sensitive film p-type silicon
Metal connectors

Figure 4. Schematics of a (a) MOSFET with p-type silicon as a base substrate (pink) and n-doped source and drain region (green) (b) ISFET with a pH sensitive film (orange) (c) Back gated FET with analyte solution and RE on the top side and all the terminal connections are done from the back side (d) Extended gate FET with a regular MOSFET and an extended sensing region connected with gate terminal of the MOSFET. S, G, D and B are source, drain, gate and base substrate terminals (all shown in black). RE is the reference electrode.

Commonly used $\mathrm{pH}$ sensitive materials for ISFETs are silicon nitride $\left(\mathrm{Si}_{3} \mathrm{~N}_{4}\right)$, aluminum oxide $\left(\mathrm{Al}_{2} \mathrm{O}_{3}\right)$, and tantalum oxide $\left(\mathrm{Ta}_{2} \mathrm{O}_{5}\right)$ [9,40-42,44-46]. $\mathrm{pH}$ sensitivity is a surface phenomenon where the surface hydroxyl groups interact with the protons. The consequent changes in the surface charge or potential of the gate material leads to a current flow in the channel. This generated current is proportional to the analyte concentration. ISFETs are increasingly popular due to advantages such as rapid detection, small size, established manufacturing process, easy integrability in arrays, and their ability to be stored in dry form. However, they suffer from higher drift as compared to ion selective electrodes.

Based on its design, the ISFETs can be front side and back side connected. Front side ISFETs are widely used due to ease of fabrication, but they make it difficult to passivate the device from the analyte solution. Back side ISFETs solve the passivation problem as 
all the connections are accessed from the back side of the silicon chip. However, it poses a manufacturing difficulty to etch a deeper cavity into the silicon chip for connecting the source and drain from the back side of the chip (Figure 4c). An alternate configuration known as an extended gate FET was proposed in 1983 [47] (Figure 4d). The device has two components: a MOSFET with electrical connections and an extended gate with a $\mathrm{pH}$ sensitive film. This device has advantages such as low manufacturing cost due to simpler fabrication and packaging, and long term environmental stability of the device as the FET is not directly exposed to the solution.

\section{Chemiresistive Sensors}

Chemiresistive sensors were initially developed to detect gases or vapors but in the past two decades several chemiresistive sensors have also been developed to measure analytes in liquid environments. These sensors consist of two main components: an active thin film and electrical contacts (Section 2.1). One of the first $\mathrm{H}_{2} \mathrm{O}_{2}$ chemiresistive sensor was fabricated from polypyrrole and multiwalled CNT (MWCNT) [48]. Chemiresistive sensors can be broadly classified based on active sensing thin film material. The active thin film can be made of various conducting or semiconducting materials such as CNTs [19,48,49], conducting polymers $[20,50,51]$ or combinations of these materials. Contact electrodes are made of conductive materials including conductive carbon [50,51], metal electrodes like platinum [48], gold [19,20,52], and silver [49]. The sensors are compared based on three parameters: measuring range, LOD and response time. A summary of $\mathrm{H}_{2} \mathrm{O}_{2}$ chemiresistive sensors is given in Table 1.

\subsection{Chemiresistive Sensors Based on CNTs}

CNTs are widely used for fabricating sensing surfaces due to their superior transduction as well as electrical and mechanical properties. Some of the features offered by CNTs include good sensitivity to change in resistance due to analyte binding, high surface-area to volume ratio and good electrical conductivity. However, CNTs pose some challenges like poor solubility in common solvents resulting in unstable dispersions which may affect the reliable fabrication of these sensors. Therefore, several dispersing molecules like sodium dodecylbenzenesulphonate (NaDBS) [48] or poly(4-vinylpyridine) (PVP) [19] have been investigated to stabilize the dispersions and facilitate reliable fabrication such as in the case of glucose detection when coated with glucose oxidase (GOD).

One of the first chemiresistive sensors prepared using CNTs used NaDBS as the dispersant to stabilize the colloid. The sensing layer was a composite of CNTs, polypyrrole and NaDBS. Here, NaDBS acted as a dopant for polypyrrole and dispersant for MWCNTs (described in Section 3.2) [48]. The sensor exhibited a measuring range from 0-20 mM for $\mathrm{H}_{2} \mathrm{O}_{2}$. The study demonstrated a chemiresistive sensor fabricated using CNTs and polypyrrole, but it did not investigate the effect of interferent species on its response. The sensor was also found to be sensitive to environmental parameters such as temperature and $\mathrm{pH}$. Another CNT based chemiresistive sensor was fabricated using a composite containing SWCNTs and PVP [19] (Figure 5a). PVP was used as the dispersing agent and the polymer also offers nucleophilic sites (pyridyl nitrogen) for electrostatic modification of the layer. GOD was drop casted followed by treatment with glutaraldehyde to crosslink the enzyme. According to previous literature reports, glucose in presence of oxygen is catalyzed by GOD to generate gluconic acid and $\mathrm{H}_{2} \mathrm{O}_{2}$ [48]. Glucose was detected by measuring the increase in current due to the generation of $\mathrm{H}_{2} \mathrm{O}_{2}$. The detection was performed under a potential bias of $0.1 \mathrm{~V}$ at $\mathrm{pH} 5.5$ with a linear range from $0.08-2.2 \mathrm{mM}$ and $0.08 \mathrm{M}$ as the LOD (Figure $5 b$ ). The sensor did not respond to interferents such as fructose and sucrose, but other potential interferents such as ascorbic acid, uric acid, were not included in the study. The sensor had a quick response time of $3 \mathrm{~s}$. However, a large variation of $\sim 18.9 \%$ was found between different sensors indicating a need to standardize the fabrication process. The study also reported that peroxide caused irreversible change on the sensor which 
limited its use to 5 times. The sensor retained $83.3 \%$ of the initial response after 45 days of storage at $4{ }^{\circ} \mathrm{C}$.
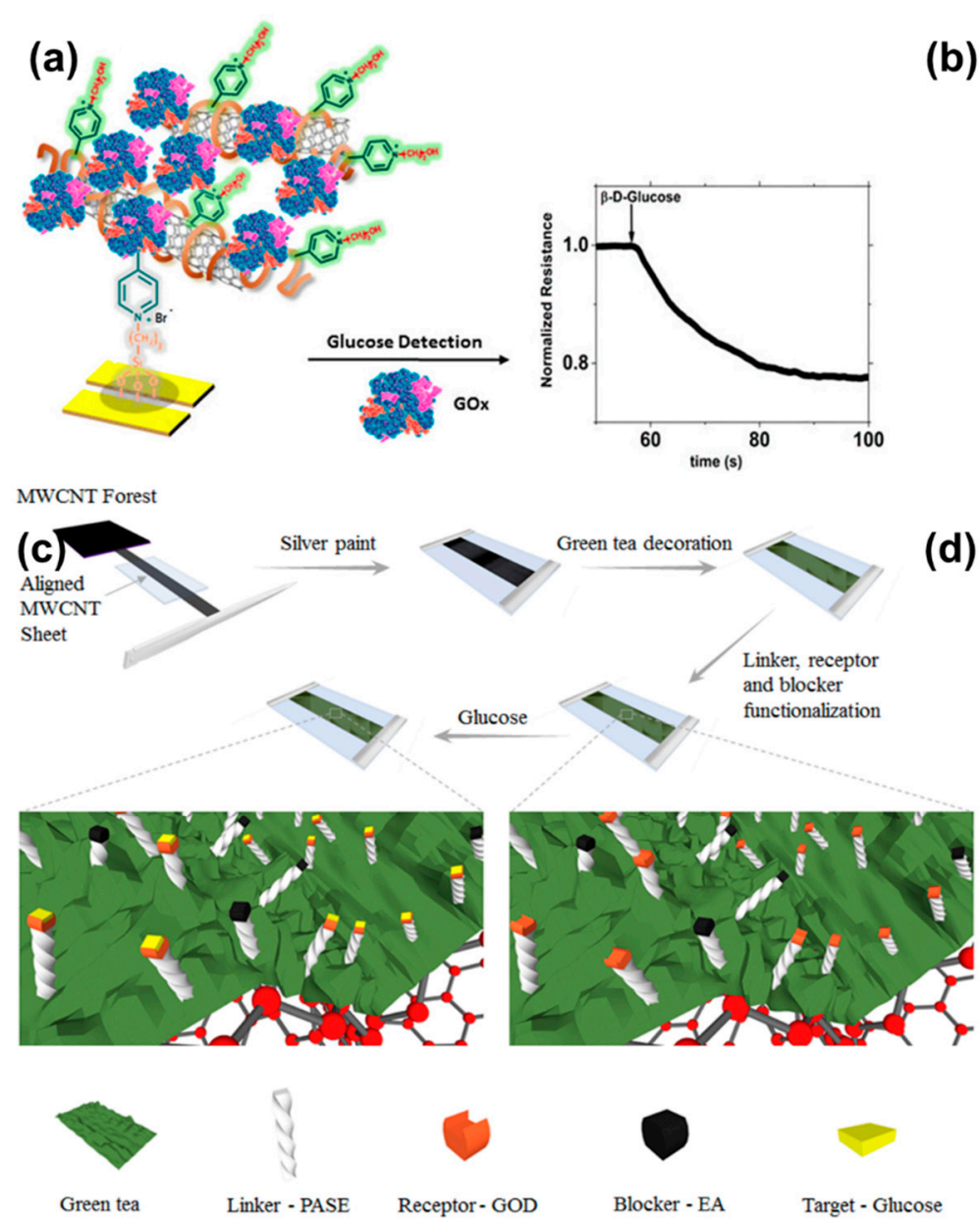

(d)
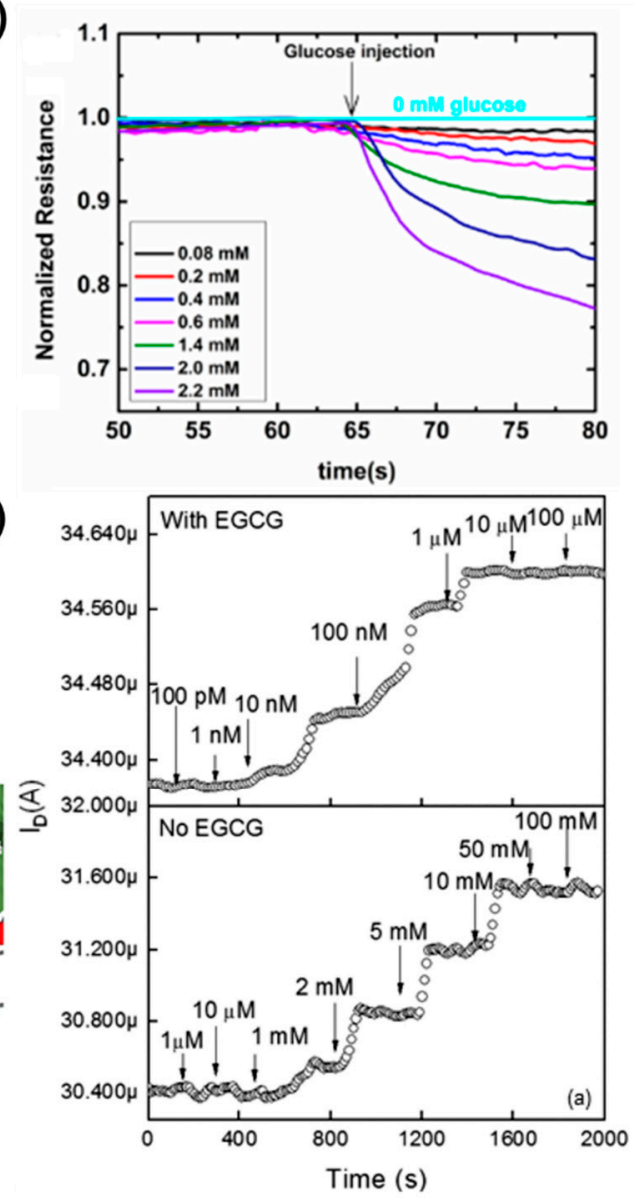

Figure 5. (a) A chemiresistive glucose sensor with GOD immobilized on a MWCNT-PVP film. A reduction in resistance is observed when the sensor is exposed to the glucose concentrations. Reprinted with permission from [19]. Copyright 2017 American Chemical Society. (b) Normalized resistance change of the sensor shown in Figure 5a, when it is exposed to glucose concentrations ranging from $0.08 \mathrm{mM}$ to $2.2 \mathrm{mM}$. Reprinted with permission from [19]. Copyright 2017 American Chemical Society. (c) Schematics showing the steps for sensor fabrication with green tea and MWCNT and GOD. Reprinted from [49] with permission from Elsevier. (d) The current response for the sensor depicted in Figure $5 \mathrm{c}$ with and without EGCG. Reprinted from [49] with permission from Elsevier.

Apart from CNT dispersions, CNTs can be transferred from the grown surface to the substrate. Here, the sensor was fabricated on a PET sheet and a chemical vapor deposited CNT film was transferred to it [49]. A reactive oxidative species sensitive molecule, epigallocatechin gallate (EGCG), a compound found in green tea, was coated on the MWCNT film. GOD was immobilized using pyrene butanoic succinimidyl ester where the pyrene ring interacts with EGCG, and the succinimidyl ester forms an amide bond with GOD (Figure 5c). The sensor measured glucose concentrations from $10 \mathrm{nM}$ to $10 \mu \mathrm{M}$ with a LOD of $\sim 8.7 \mathrm{nM}$ when operated under a constant potential bias of $100 \mathrm{mV}$. In absence of EGCG, the dynamic detection range increases to $1-10 \mathrm{mM}$ (Figure 5d). Without EGCG, the $\mathrm{H}_{2} \mathrm{O}_{2}$ molecules directly p-dope the CNT film and change the resistance. However, in presence of EGCG, direct doping by the $\mathrm{H}_{2} \mathrm{O}_{2}$ molecules is limited. The change in resistance is mainly due to oxidation of EGCG by $\mathrm{H}_{2} \mathrm{O}_{2}$ and a subsequent p-doping shifts the detection range to a lower concentration range. No significant interference was observed in presence of acetaminophen, ascorbic acid, and uric acid. Even though the sensor showed an estimated 
response time of $\sim 400 \mathrm{~s}$ which was higher as compared to the PVP-CNT sensor [19], it can be used to detect $\mathrm{H}_{2} \mathrm{O}_{2}$ in sub micromolar ranges (>10 nM).

\subsection{Chemiresistive Sensors Based on Conducting Polymers}

Conducting polymers are of great interest in sensing due to their properties like mechanical flexibility, simple synthesis process, and good conductivity. One of the earliest $\mathrm{H}_{2} \mathrm{O}_{2}$ sensors based on a conducting polymer was constructed using polypyrrole due to its biocompatibility, easy processing and fabrication, and significant effect on conductivity in the presence of redox dopants [48]. The electropolymerized polypyrrole film exhibited a conductivity change in presence of $\mathrm{H}_{2} \mathrm{O}_{2}$ due to the introduction of additional holes in the film. The study compares the sensor performance of two types of films: one with GOD encapsulated on polypyrrole film and other with GOD encapsulated in the polypyrrole-MWCNT film to detect glucose. The sensor was found to measure $\mathrm{H}_{2} \mathrm{O}_{2}$ over a concentration range of $0-20 \mathrm{mM}$ with a sensitivity of $0.9 \mathrm{mS} \mathrm{cm}^{-1} \mathrm{mM}^{-1}$. The sensitivity of the sensor was enhanced to $2.6 \mathrm{mS} \mathrm{cm}{ }^{-1} \mathrm{mM}^{-1}$ ( 3 times) by introducing MWCNTs with polypyrrole as the active thin film. However, the sensor was also found to be sensitive to environmental parameters like mechanical stress, temperature, and oxygen concentration. This study did not investigate the effect of interferent species and real samples on the sensor performance.

Polyaniline is another conducting polymer that has been used for $\mathrm{H}_{2} \mathrm{O}_{2}$ measurement $[20,51,52]$ and subsequently used the sensor for glucose detection [50]. The conductivity of polyaniline strongly depends on the $\mathrm{pH}$ value of the solution and this property is used in $\mathrm{H}_{2} \mathrm{O}_{2}$ detection [20]. A polyaniline nanowire network was used for sensor preparation. Nanowires were used due to their superior sensing performance like rapid response time, higher sensitivity, and improved LOD due to increased surface area, and high porosity [50]. The nanowires were modified with silver nanoparticles (AgNPs) which catalyze the $\mathrm{H}_{2} \mathrm{O}_{2}$ reaction to generate hydroxy ions as a by-product that increases the $\mathrm{pH}$ in the vicinity [20]. The introduction of AgNPs improved the sensor response from $3 \%$ (no AgNPs) decrease in conduction current to $20 \%$ (with AgNPs), when both sensors were exposed to $20 \mathrm{mM} \mathrm{H}_{2} \mathrm{O}_{2}$. The increased $\mathrm{H}_{2} \mathrm{O}_{2}$ concentration results in increase in $\mathrm{pH}$ which leads to decrease in conductivity of the polyaniline film. The measuring range of the sensor was $5-40 \mathrm{mM}$ of $\mathrm{H}_{2} \mathrm{O}_{2}$. Moreover, the sensor can be used multiple times by regenerating the sensor surface using an electrochemical method [53]. Sensors were stable during $36 \mathrm{~h}$ testing.

The same group demonstrated a conducting polymer based multiple analyte detection platform. The sensing platform was used to test three physiological relevant analytes: $\mathrm{H}_{2} \mathrm{O}_{2}$, dopamine and ascorbic acid within a range of 1-10 $\mathrm{mM}$ for all three analytes [52]. The response time of the sensors was around $2 \mathrm{~min}$. The sensor panel provides a generic platform which can be applied to measure the required analyte by changing the surface coatings. Further, the group reported a low-cost method of fabricating the sensor using inkjet printing [51]. The process was validated by fabricating a $\mathrm{H}_{2} \mathrm{O}_{2}$ sensor using polyaniline nanowires and Ag NPs. The fabricated sensor exhibited a measuring range of 1-20 mM with a response time of $3 \mathrm{~min}$. The minimum printing resolution was around $200 \mu \mathrm{m}$ which can be used to fabricate chemiresistors.

Later, Platinum nanoparticles were used with immobilized GOD to fabricate a chemiresistive sensor for glucose detection [50]. The sensor was printed using an inkjet printer described in their previous work [51]. GOD catalyzes the conversion of glucose to gluconic acid and $\mathrm{H}_{2} \mathrm{O}_{2}$. The generated $\mathrm{H}_{2} \mathrm{O}_{2}$ is converted to hydroxide ions which is catalyzed by the platinum nanoparticles. The produced hydroxide ions resulted in a local $\mathrm{pH}$ change which subsequently changes the conductivity of the PANI nanowire layer. The PANI nanowire layer showed good reproducibility with a standard deviation of $2.7 \%(n=5)$. The authors demonstrated a low-cost glucose sensor with a simple fabrication process with a linear measuring range of $2-10 \mathrm{mM}$ with a LOD of $2 \mathrm{mM}$. The sensor measuring range (2-10 $\mathrm{mM})$ was wider as compared to the SWCNT-PVP sensor reported $(0.02-2 \mathrm{mM})$ [19]. 
However, the study does not comment on the effect on sensor response due to interfering species and physiological matrices like blood, urine, etc.

Table 1. A list of $\mathrm{H}_{2} \mathrm{O}_{2}$ chemiresistive sensors with the crucial sensor properties including LOD, measuring range, voltage bias, response time, buffer and working $\mathrm{pH}$. All units are as mentioned in the top row unless specified. Where NR: Not reported, PPy: Polypyrrole, PANI: Polyaniline, Pt NPs: Platinum nanoparticles, $\mathrm{SnO}_{2}$ : Tin oxide, Au: Gold.

\begin{tabular}{|c|c|c|c|c|c|c|c|c|c|c|}
\hline Substrate & $\begin{array}{c}\text { Target } \\
\text { Analyte }\end{array}$ & $\begin{array}{l}\text { Ligand/ } \\
\text { Enzyme }\end{array}$ & $\begin{array}{l}\text { LOD } \\
(\mathrm{mM})\end{array}$ & $\begin{array}{l}\text { Measuring } \\
\text { Range } \\
\text { (mM) }\end{array}$ & $\begin{array}{l}\text { Voltage } \\
\text { Bias } \\
(\mathrm{mV})\end{array}$ & $\begin{array}{c}\text { Response } \\
\text { Time (s) }\end{array}$ & $\begin{array}{c}\text { Buffer/ } \\
\text { Working } \\
\text { pH }\end{array}$ & Comments & $\begin{array}{l}\text { Interference } \\
\text { Tested }\end{array}$ & Ref \\
\hline \multicolumn{11}{|c|}{ Carbon nanotube based } \\
\hline $\begin{array}{c}\text { PPy- } \\
\text { MWCNT }\end{array}$ & $\begin{array}{c}\mathrm{H}_{2} \mathrm{O}_{2} / \\
\text { Glucose }\end{array}$ & $\begin{array}{l}\text { Dodecyl } \\
\text { benzene } \\
\text { sulfonate }\end{array}$ & NR & $0-20$ & 1 & NR & NR & $\begin{array}{c}\text { Investigated } \\
\text { the sensitivity } \\
\text { of } \\
\text { temperature } \\
\text { humidity etc. }\end{array}$ & No & [48] \\
\hline CNT & Glucose & $\begin{array}{l}\text { EGCG- } \\
\text { GOD }\end{array}$ & $\begin{array}{l}8.7 \\
\mathrm{nM}\end{array}$ & $\begin{array}{c}10 \mathrm{nM}-1 \\
\mu \mathrm{M}\end{array}$ & 100 & $\begin{array}{l}<400 \\
\text { (est.) }\end{array}$ & $\begin{array}{c}\text { Working } \\
\text { pH 7.4 } \\
\text { Buffer: PBS }\end{array}$ & $\begin{array}{l}\text { Sensor } \\
\text { responds to } \\
\text { all reactive } \\
\text { oxidative } \\
\text { species }\end{array}$ & Yes & [49] \\
\hline $\begin{array}{l}\text { SWCNT- } \\
\text { PVP }\end{array}$ & Glucose & GOD & 0.08 & $0.02-2$ & 100 & 3 & $\begin{array}{l}\text { Working } \\
\text { pH } 5.5 \\
\text { Buffer: } \\
\text { Acetate }\end{array}$ & $\begin{array}{c}\text { Tested in juice } \\
\& \text { iced tea } \\
\text { Stable for } 5 \\
\text { consecutive } \\
\text { tests }\end{array}$ & Yes & [19] \\
\hline \multicolumn{11}{|c|}{ Conducting polymer based } \\
\hline $\begin{array}{l}\text { Au-PANI } \\
\text { nanowires }\end{array}$ & $\mathrm{H}_{2} \mathrm{O}_{2}$ & AgNPs & 5 & $5-40$ & 20 & 25 & $\begin{array}{l}\text { Working } \\
\text { pH 5 } \\
\text { Buffer: } \\
\text { Phosphate } \\
(200 \mathrm{mM}) \\
\end{array}$ & $\begin{array}{c}\text { Stable } \\
\text { response for } \\
36 \mathrm{~h} \\
\text { Reusable } \\
\text { sensor }\end{array}$ & Yes & [20] \\
\hline $\begin{array}{l}\text { MWCNT- } \\
\text { PANI } \\
\text { nanowires }\end{array}$ & $\mathrm{H}_{2} \mathrm{O}_{2}$ & AgNPs & 1 & $1-20$ & NR & 180 & NR & $\begin{array}{l}\text { Inkjet printed } \\
\text { sensors }\end{array}$ & No & [51] \\
\hline $\begin{array}{l}\text { MWCNT- } \\
\text { PANI } \\
\text { nanowire }\end{array}$ & $\begin{array}{c}\mathrm{H}_{2} \mathrm{O}_{2} \\
\text { Glucose }\end{array}$ & PtNPs & 2 & $2-10$ & 500 & 240 & NR & Inkjet printed & No & [50] \\
\hline \multicolumn{11}{|c|}{ Others } \\
\hline Alumina & Glucose & $\begin{array}{l}\mathrm{SnO}_{2-} \\
\mathrm{GOD}\end{array}$ & $\begin{array}{c}0.5 \\
\text { (est.) }\end{array}$ & $0.5-20$ & NR & 50 & $\begin{array}{c}\text { Working } \\
\text { pH 7.2 } \\
\text { Buffer: } \\
\text { Phosphate }\end{array}$ & $\begin{array}{c}\text { Sensor } \\
\text { sensitivity } \\
\text { increases with } \\
\text { deposition } \\
\text { temperature } \\
\text { of } \mathrm{SnO}_{2}\end{array}$ & No & [54] \\
\hline
\end{tabular}

\subsection{Chemiresistive Sensors Based on Other Materials}

Metal oxides have been used to measure $\mathrm{H}_{2} \mathrm{O}_{2}$ using a chemiresistive geometry. For instance, a nanostructured $\mathrm{SnO}_{2}$ film on an alumina substrate along with immobilized GOD has been used to sense $\mathrm{H}_{2} \mathrm{O}_{2}$ and through that measure glucose [54]. The sensitivity of the $\mathrm{SnO}_{2}$ layer is due to adsorption of molecular oxygen (Reaction 3) and its reduction through the extraction of electrons from the conduction band of the $\mathrm{SnO}_{2}$ film.

$$
\mathrm{O}_{2}+2 \mathrm{e}^{-} \rightarrow 2 \mathrm{O}_{\mathrm{ads}}^{-}
$$

The electron extraction increases the potential barrier which in turn leads to a decrease in conduction. Upon exposure to GOD, glucose is converted to gluconic acid and $\mathrm{H}_{2} \mathrm{O}_{2}$, the gluconic acid converts to D-gluconate and $\mathrm{H}^{+}$. This $\mathrm{H}^{+}$and $\mathrm{H}_{2} \mathrm{O}_{2}$ react with the $\mathrm{O}_{\text {ads }}^{-}$ to release the electron extracted from the conduction band of the tin oxide film, resulting in 
an increase in resistance. A suitable catalyst can further improve the sensor performance. A linear range was reported from 0.5 to $20 \mathrm{mM}$ with the highest sensitivity when the tin oxide film was grown at $450{ }^{\circ} \mathrm{C}$.

\section{Conductometric Sensors}

One of the earliest conductometric sensors for $\mathrm{H}_{2} \mathrm{O}_{2}$ was developed in 1999 [43]. The sensor was constructed using tetra-tert-butyl copper phthalocyanine (ttb-CuPc) coated gold interdigitated electrodes on a ceramic substrate (Figure 6a). The phthalocyanine film was deposited using the Langmuir-Blodgett method. The sensing of $\mathrm{H}_{2} \mathrm{O}_{2}$ was based on oxidation of iodide ions by $\mathrm{H}_{2} \mathrm{O}_{2}$ in the presence of HRP (Reaction 1). The iodine concentration was measured by a conductometric sensor based on ttb-CuPc as the sensing layer. The effect of other interfering species in the sample was suppressed using a hydrophobic gas permeable membrane. HRP was immobilized on top of the gas permeable membrane. The sensor attained a steady state response in $\sim 10 \mathrm{~min}$ which was due to slow conductivity changes in the phthalocyanine film. The highest sensor response was obtained within a $\mathrm{pH}$ range of 5.0-6.5. The measuring range was 0.005 to $0.3 \mathrm{mM}$ with a sensitivity of $0.042 \mu \mathrm{S} / \mu \mathrm{M}$ of $\mathrm{H}_{2} \mathrm{O}_{2}$. The sensor worked continuously for $7 \mathrm{~h}$ with more than 30 measurements and had a storage stability of 90 days when stored at $4{ }^{\circ} \mathrm{C}$.

(a)
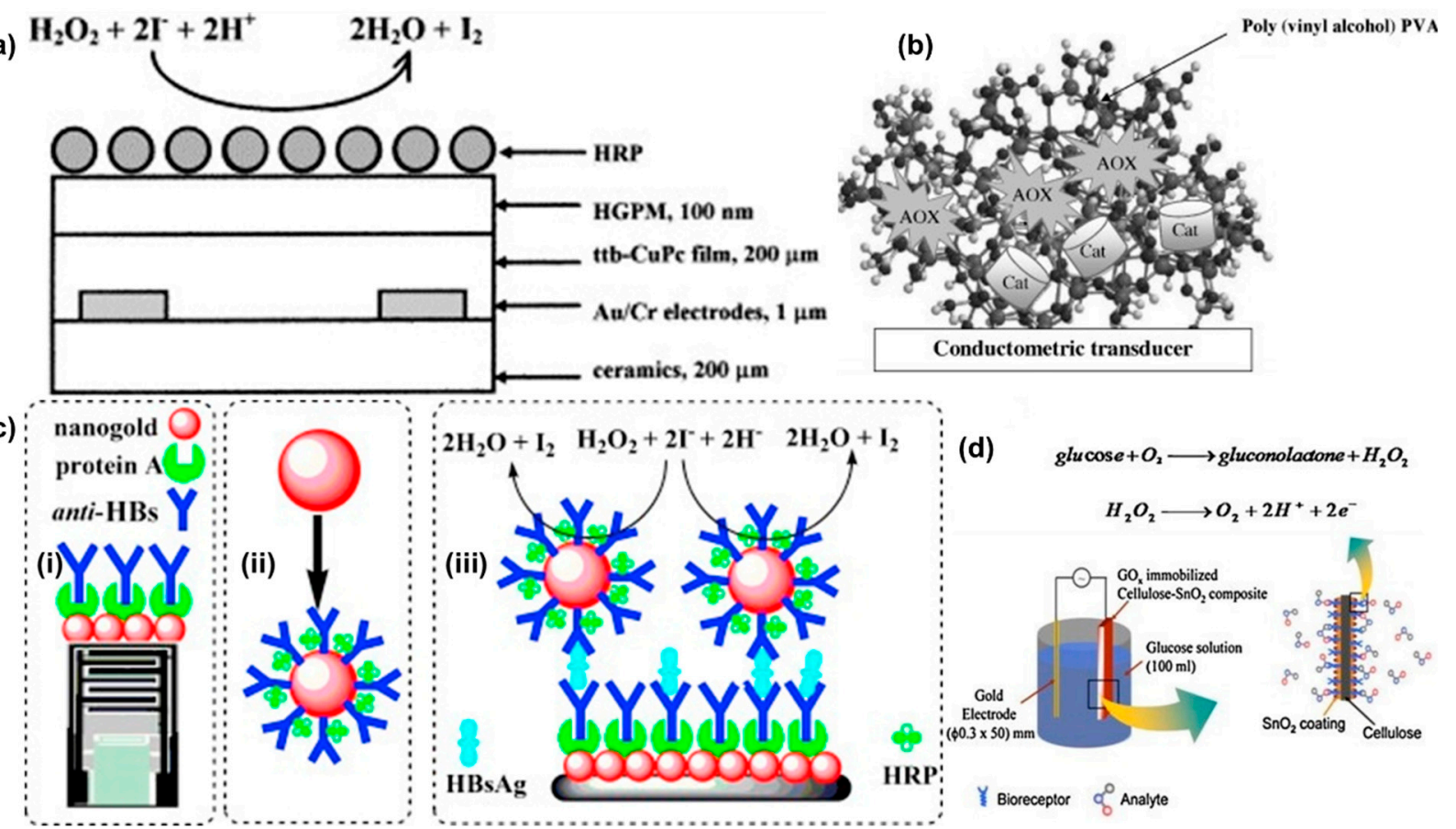

HGPM, $100 \mathrm{~nm}$ ttb-CuPc film, $200 \mu \mathrm{m}$ Au/Cr electrodes, 1 um ceramics, $200 \mu \mathrm{m}$

(d) glucose $+\mathrm{O}_{2} \longrightarrow$ gluconoladone $+\mathrm{H}_{2} \mathrm{O}_{2}$ $\mathrm{H}_{2} \mathrm{O}_{2} \longrightarrow \mathrm{O}_{2}+2 \mathrm{H}^{+}+2 e^{-}$

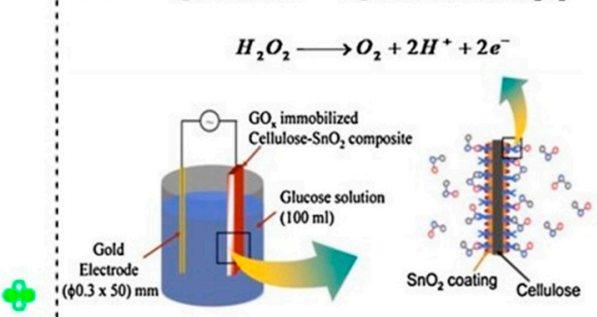

Figure 6. (a) A HRP conductometric sensor for enzymatic detection of $\mathrm{H}_{2} \mathrm{O}_{2}$. The sensor was fabricated using $\mathrm{HRP}$ as the enzyme and $\mathrm{ttb}-\mathrm{CUPc}$ as the active/sensitive film to detect the released iodine molecule. Reprinted from [38] with permission from Elsevier. (b) A bi-enzyme sensor (Alcohol oxidase and catalase) to detect alcohol using conductometric transducer. Reprinted from [39] with permission from Elsevier. (c) (i) Schematics of a conductometric transducer working as an immunosensor (ii) A nanogold particle coated with anti-HBs and protein A (iii) Schematics of the sandwich immunoassay with the reactions involved to measure Hepatitis-B surface antigens. Reprinted from [42] with permission from Elsevier. (d) Schematics of a GOD immobilized cellulose- $\mathrm{SnO}_{2}$ composite electrode. Reprinted from [46] with permission from Elsevier.

Since then, multiple conductometric sensors have been reported in the literature. These sensors can be classified based on electrode material used for the sensors such as metal [43,55-57], metal nanoparticles [21-23,58], and others [59]. The sensors are compared based on crucial parameters like sensitivity, measuring range, LOD, potential bias, and response time. A summary of conductometric sensors is given in Table 2. 
Table 2. Summary of $\mathrm{H}_{2} \mathrm{O}_{2}$ conductometric sensors with the crucial sensor properties including LOD, measuring range, voltage bias, response time, buffer and working $\mathrm{pH}$. Where AOX: Alcohol oxidase, PVA: Polyvinyl alcohol, g- $\mathrm{C}_{3} \mathrm{~N}_{4}$ : graphitic carbon nitride, Au: Gold, AuNPs: Gold nanoparticles, AFP: alpha-fetoprotein, LOD: Lactate oxidase.

\begin{tabular}{|c|c|c|c|c|c|c|c|c|c|c|}
\hline Substrate & $\begin{array}{l}\text { Target } \\
\text { Analyte }\end{array}$ & $\begin{array}{l}\text { Ligand/ } \\
\text { Enzyme }\end{array}$ & $\begin{array}{l}\text { LOD } \\
(\mu \mathrm{M})\end{array}$ & $\begin{array}{l}\text { Measuring } \\
\text { Range } \\
\text { (mM) }\end{array}$ & $\begin{array}{l}\text { Voltage Bias } \\
(\mathrm{mV}) \\
\text { (Frequency) }\end{array}$ & $\begin{array}{l}\text { Response } \\
\text { Time } \\
\text { (Minutes) }\end{array}$ & $\begin{array}{c}\text { Buffer/ } \\
\text { Working pH }\end{array}$ & Comments & $\begin{array}{l}\text { Interference } \\
\text { Tested }\end{array}$ & Ref \\
\hline \multicolumn{11}{|c|}{ Metal interdigitated electrodes } \\
\hline Ceramic-Au & $\mathrm{H}_{2} \mathrm{O}_{2}$ & Pthalocyanine & NR & $0.005-0.3$ & 60 & 10 & $\begin{array}{c}\text { Working pH } 6.0 \\
\text { Buffer: } \\
\text { Phosphate } \\
(20 \mathrm{mM})\end{array}$ & $\begin{array}{l}\text { Storage stability } \\
\text { for } 90 \text { days at } \\
4^{\circ} \mathrm{C}\end{array}$ & No & [43] \\
\hline Silicon-Au & $\begin{array}{c}\mathrm{H}_{2} \mathrm{O}_{2} / \\
\text { Cyanide }\end{array}$ & $\begin{array}{l}\text { PVA- } \\
\text { Catalase }\end{array}$ & 6 & $0-100$ & $\begin{array}{c}10 \\
(100 \mathrm{kHz})\end{array}$ & 5 & $\begin{array}{c}\text { Working pH } 7.2 \\
\text { Buffer: } \\
\text { Phosphate } \\
(5 \mathrm{mM})\end{array}$ & $\begin{array}{l}\text { Inhibitory assay } \\
\text { for cyanide } \\
\text { detection }\end{array}$ & No & [56] \\
\hline \multirow{3}{*}{$\mathrm{Au}$} & Methanol & \multirow{3}{*}{$\begin{array}{c}\text { AOX- } \\
\text { Catalase }\end{array}$} & 0.5 & $<0.075$ & \multirow{3}{*}{$\begin{array}{c}10 \\
(100 \mathrm{kHz})\end{array}$} & \multirow{3}{*}{$<10$} & \multirow{3}{*}{$\begin{array}{c}\text { Working pH } 7.2 \\
\text { Buffer: } \\
\text { Phosphate } \\
(5 \mathrm{mM})\end{array}$} & \multirow{3}{*}{$\begin{array}{l}\text { Alcoholic } \\
\text { beverages }\end{array}$} & \multirow{3}{*}{ Yes } & \multirow{3}{*}{ [55] } \\
\hline & Ethanol & & 1 & $<0.070$ & & & & & & \\
\hline & Propanol & & 3 & $<0.065$ & & & & & & \\
\hline Ceramic-Au & Lactate & LOD-HRP & 0.05 & $0-0.21$ & $\begin{array}{c}10 \\
(100 \mathrm{kHz})\end{array}$ & $\sim 20$ (est.) & $\begin{array}{l}\text { Working pH } 6 \\
\text { Buffer: } \\
\text { Phosphate } \\
(5 \mathrm{mM})\end{array}$ & $\begin{array}{l}\text { Diluted yogurt } \\
\text { samples } \\
\text { Storage stability } \\
\text { for } 40 \text { days at } \\
\quad 4{ }^{\circ} \mathrm{C}\end{array}$ & Yes & [57] \\
\hline \multicolumn{11}{|c|}{ Metal nanoparticles } \\
\hline AuNPs & $\begin{array}{l}\text { Hepatitis } \\
\text { B (HB) }\end{array}$ & $\begin{array}{c}\text { HRP / Anti- } \\
\text { HBs }\end{array}$ & $\begin{array}{c}0.01 \\
\mathrm{ng} / \mathrm{mL}\end{array}$ & $\begin{array}{l}0.1-600 \\
\mathrm{ng} / \mathrm{mL}\end{array}$ & $\begin{array}{c}10 \\
(100 \mathrm{kHz})\end{array}$ & $>30$ & $\begin{array}{l}\text { Working pH } 7.0 \\
\text { Buffer: } \\
\text { Phosphate (10 } \\
\text { mM) }\end{array}$ & $\begin{array}{l}\text { Tested with } \\
\text { serum samples } \\
\text { Assay stable for } \\
16 \text { days when } \\
\text { stored at } 4^{\circ} \mathrm{C}\end{array}$ & Yes & [58] \\
\hline $\begin{array}{l}\text { Ceramic-Au } \\
\& \text { magnetic } \\
\text { NPs }\end{array}$ & Glucose & GOD & 3 & $0.04-3$ & $\begin{array}{c}10 \\
(100 \mathrm{kHz})\end{array}$ & $<10$ & $\begin{array}{l}\text { Working pH } 7.3 \\
\text { Buffer: } \\
\text { Phosphate (5 } \\
\text { mM) }\end{array}$ & $\begin{array}{l}\text { Stable for } 12 \\
\text { days when } \\
\text { stored at } 4^{\circ} \mathrm{C}\end{array}$ & No & [23] \\
\hline $\mathrm{g}-\mathrm{C}_{3} \mathrm{~N}_{4}$ & $\mathrm{AFP} / \mathrm{H}_{2} \mathrm{O}_{2}$ & Pt NPs & $\begin{array}{c}0.01 \\
\mathrm{ng} / \mathrm{mL}\end{array}$ & $\begin{array}{c}0.01-100 \\
\mathrm{ng} / \mathrm{mL}\end{array}$ & $\begin{array}{c}10 \\
(100 \mathrm{kHz})\end{array}$ & $5-6$ & $\begin{array}{c}\text { Working pH } 6.5 \\
\text { Buffer: PBS (10 } \\
\text { mM) }\end{array}$ & $\begin{array}{l}\text { Tested with } \\
\text { human serum } \\
\text { Inhibitory } \\
\text { Immunoassay }\end{array}$ & Yes & [21] \\
\hline \multicolumn{11}{|c|}{ Others } \\
\hline $\begin{array}{l}\text { Cellulose- } \\
\mathrm{SnO}_{2}\end{array}$ & $\begin{array}{l}\mathrm{H}_{2} \mathrm{O}_{2} / \\
\text { Glucose }\end{array}$ & GOD & 500 & $0.5-12$ & $0-3 \mathrm{~V}(\mathrm{dc})$ & NR & $\begin{array}{c}\text { Working pH } 7.2 \\
\text { Buffer: } \\
\text { Phosphate }\end{array}$ & $\begin{array}{c}\text { Storage stability } \\
>10 \text { days } \\
\text { Flexible } \\
\text { one-time use } \\
\text { sensor }\end{array}$ & No & [59] \\
\hline
\end{tabular}

\subsection{Conductometric Sensors Based on Metal Electrodes}

Similar to the first $\mathrm{H}_{2} \mathrm{O}_{2}$ conductometric sensor, many sensors were prepared using interdigitated gold electrodes. One such sensor was prepared using a polyvinyl alcohol membrane to immobilize catalase [56], an enzyme that converts $\mathrm{H}_{2} \mathrm{O}_{2}$ to water. The measurement was done using an $\mathrm{AC}$ bias of $10 \mathrm{mV}$ and $100 \mathrm{kHz}$ frequency. The electrodes exhibited a linear range wider than the phthalocyanine sensor [43] from 0-100 mM $\mathrm{H}_{2} \mathrm{O}_{2}$ with a detection limit of $6 \mu \mathrm{M}$. The sensitivity of the sensor was $1 \mu \mathrm{S} / \mu \mathrm{M}$ of $\mathrm{H}_{2} \mathrm{O}_{2}$ which was around 20 times higher than the phthalocyanine $\mathrm{H}_{2} \mathrm{O}_{2}$ conductometric sensor $(0.042 \mu \mathrm{S} / \mu \mathrm{M})$ [43]. The response time of the sensor was less than $5 \mathrm{~min}$, which was half of the previous sensor ( 10 $\mathrm{min})$ [43]. Interestingly, the sensor was shown to respond to cyanide as an interfering species due to the inhibitory effect of cyanide on the catalase enzyme.

Similar to glucose sensors, alcohols were also detected using alcohol oxidase enzyme (Reaction 4). The alcohol concentration can be correlated to either the decrease in oxygen or increase in hydrogen peroxide concentration. A dual enzyme sensor based on alcohol oxidase (AOX) and catalase was used to detect lower aliphatic alcohols including methanol, ethanol, and n-propanol [55]. The proposed dual enzyme system is one of the first such 
studies reported to measure the alcohol concentrations (Figure 6b). The generated $\mathrm{H}_{2} \mathrm{O}_{2}$ can be used by the catalase to convert it to oxygen and water (Reactions 4-6).

$$
\begin{gathered}
\mathrm{RCH}_{2} \mathrm{OH}+\mathrm{O}_{2} \stackrel{\mathrm{AOX}}{\rightarrow} \mathrm{RCHO}+\mathrm{H}_{2} \mathrm{O}_{2} \\
2 \mathrm{H}_{2} \mathrm{O}_{2} \stackrel{\text { Catalase }}{\rightarrow} \mathrm{O}_{2}+\mathrm{H}_{2} \mathrm{O} \\
\mathrm{CH}_{3} \mathrm{CH}_{2} \mathrm{OH}+\mathrm{H}_{2} \mathrm{O}_{2} \stackrel{\text { Catalase }}{\rightarrow} \mathrm{CH}_{3} \mathrm{CHO}+2 \mathrm{H}_{2} \mathrm{O}
\end{gathered}
$$

To fabricate the sensor, enzymes were immobilized on a polyvinyl alcohol photopolymerized network. The sensor showed a linear range for the three test alcohols: methanol, ethanol, and n-propanol up to $0.075 \mathrm{mM}, 0.070 \mathrm{mM}$ and $0.065 \mathrm{mM}$, respectively. In addition, an increase in the number of carbons in the alcohols resulted in a higher LOD with $0.5 \mu \mathrm{M}$ for methanol, $1 \mu \mathrm{M}$ for ethanol and $3 \mu \mathrm{M}$ for n-propanol. The sensitivities of the sensors were $0.394,0.363$ and $0.317 \mu \mathrm{S} / \mu \mathrm{M}$ of methanol, ethanol and n-propanol which was around one order higher than the phthalocyanine $\mathrm{H}_{2} \mathrm{O}_{2}$ conductometric sensor $(0.042 \mu \mathrm{S} / \mu \mathrm{M})$ [43]. Sensors were stable for 3-4 months when stored in phosphate buffer at $4{ }^{\circ} \mathrm{C}$. The sensor response was stable for three months with no significant changes when used 2-3 times a week. However, a 5\% reduction in sensor response was observed at the end of the 4 th month. There was no significant interference from compounds like lactic acid, ascorbic acid, oxalic acid, malic acid, glucose, tartaric acid, and citric acid.

For immobilized enzyme conductometric electrodes, the sample matrix can have a significant influence on the sensor response. Therefore, a second electrode which lacks enzyme coating was used to normalize the influence of the matrix. For example, a sensor with two electrodes was proposed to detect lactate in dairy products [57]. The sensing system consists of two pair of interdigitated gold electrodes fabricated on a ceramic substrate $\left(\mathrm{Al}_{2} \mathrm{O}_{3}\right)$. The working electrode was coated with lactate oxidase and HRP while the second electrode was coated with a non-reactive bovine serum albumin layer. All measurements were performed at $10 \mathrm{mV}$ AC bias with $100 \mathrm{kHz}$ frequency in phosphate buffer at $\mathrm{pH} 6$. The sensitivity of $5.58 \mu \mathrm{S} / \mu \mathrm{M}$ of lactate was two orders of magnitude higher than that of the first $\mathrm{H}_{2} \mathrm{O}_{2}$ conductometric sensor $(0.042 \mu \mathrm{S} / \mu \mathrm{M})$ [43]. The sensor showed a low detection limit of $0.05 \mu \mathrm{M}$. The biosensor was stable for up to five weeks when stored at $4{ }^{\circ} \mathrm{C}$ in a phosphate buffer solution and used intermittently. The sensor was tested with common interferents like glucose, fructose, and ascorbic acid. Apart from ascorbic acid, none of the compounds had a significant effect on the sensor's response. The sensor was also tested in modified yogurt.

\subsection{Conductometric Sensors Based on Metal Nanoparticles}

Conductometric sensors have been fabricated using mainly two types of nanoparticles: gold [22,23,58], and platinum [21]. Nanoparticles provides a high surface to volume ratio resulting in an increase in enzyme loading which in turn could led to increased sensitivity of the sensor. One such study used both gold and magnetic nanoparticles to detect glucose [23]. Planar interdigitated electrodes were used to evaluate the effect of nanoparticles on the analytical performance of the glucose conductometric sensors. The measurements were performed using a $10 \mathrm{mV}$ and $100 \mathrm{kHz}$ frequency signal in phosphate buffer at $\mathrm{pH}$ 7.3. The gold nanoparticles functionalization increased the sensitivity of the sensor from $31 \mu \mathrm{S} / \mathrm{mM}$ (without) to $45 \mu \mathrm{S} / \mathrm{mM}$ (with). The LOD was also decreased from $50 \mu \mathrm{M}$ (without) to $9 \mu \mathrm{M}$ (with nanoparticles). The linear range for both with and without gold nanoparticles was 0.04 to $1 \mathrm{mM}$. The study further explores the sensor response with magnetic nanoparticles (Carboxy-Adambeads). The sensitivity was enhanced to $75 \mu \mathrm{S} / \mathrm{mM}$ of glucose concentration with a LOD of $3 \mu \mathrm{M}$. The study failed to provide a valid explanation for increased sensitivity with magnetic nanoparticles as compared to gold nanoparticles. Gold nanoparticles were also used in combination with chitosan to immobilize HRP for $\mathrm{H}_{2} \mathrm{O}_{2}$ detection [22]. The sensor uses chitosan to immobilize HRP due to its excellent mechanical strength, 
Biocompatibility, non-toxicity, high permeability, and superior film forming ability. The sensor exhibited a linear response from $0-15 \mathrm{mM}$ of $\mathrm{H}_{2} \mathrm{O}_{2}$ concentration. However, this sensor used high potential from $0-6 \mathrm{~V}$ for measurements which might not be ideal for sensing biomolecules.

Nanoparticles were also used to fabricate conductometric immunosensors for the detection of $\mathrm{H}_{2} \mathrm{O}_{2}$ using the $\mathrm{H}_{2} \mathrm{O}_{2}$-KI reaction (Reaction 1). A HRP-AuNP-anti-hepatitis antibody $(\mathrm{HAb})$ based sensor was proposed for detection of Hepatitis surface antigen $\mathrm{B}$, a major index for Hepatitis B [58]. The interdigitated electrode was coated with AuNPs and protein A followed by anti-HAbs. The measuring solution contained double codified AuNPs, Hepatitis B surface antigens, $\mathrm{H}_{2} \mathrm{O}_{2}$, and $\mathrm{KI}$ (Figure 6c). The addition of double codified AuNPs enhanced the sensor response. The sensor without AuNPs exhibited a linear range from $1.5-450 \mathrm{ng} / \mathrm{mL}$ which was increased to $0.1-600 \mathrm{ng} / \mathrm{mL}$ with AuNPs. The detection limit of the sensor was also improved to $0.01 \mathrm{ng} / \mathrm{mL}$ (with AuNPs) from $0.5 \mathrm{ng} / \mathrm{mL}$. A $40 \%$ increase in sensitivity was observed with the addition of the AuNPs. The sensors showed good intra $(4.9 \%)$ and inter $(7.1 \%)$ reproducibility values at $1.5 \mathrm{ng} / \mathrm{mL}$. The conductometric assay was validated using 40 serum samples against ELISA. All measurements were performed at a low potential bias of $10 \mathrm{mV}$ at $100 \mathrm{kHz}$.

Another study used graphitic carbon nitrite $\left(g-\mathrm{C}_{3} \mathrm{~N}_{4}\right)$ and platinum NPs for $\mathrm{H}_{2} \mathrm{O}_{2}$ detection. Both g- $\mathrm{C}_{3} \mathrm{~N}_{4}$ and platinum NPs (PtNPs) were used in multiple sensing research studies due to their peroxidase activity [21]. In this study, $g-C_{3} \mathrm{~N}_{4}$ nanosheets were functionalized with PtNPs to develop a conductometric immunosensor using the $\mathrm{H}_{2} \mathrm{O}_{2}$-iodide system. The nanosheets mimic a natural enzyme and reduce $\mathrm{H}_{2} \mathrm{O}_{2}$ in presence of iodide. Due to the low conductivity of the antigen-antibody complex, the immunoreaction causes a change in the conductivity. The PtNPs-g- $\mathrm{C}_{3} \mathrm{~N}_{4}$ sensor exhibited a linear response from $0-50 \mu \mathrm{M}$ of $\mathrm{H}_{2} \mathrm{O}_{2}$ where the sensor took around 5-6 min to achieve the steady state response. The peroxidase activity of the PtNPs-g- $\mathrm{C}_{3} \mathrm{~N}_{4}$ network was achieved at 6.5 which can be because of $\mathrm{H}_{2} \mathrm{O}_{2}$ adsorption at lower/higher $\mathrm{pH}$ values. The immunoassay can detect AFP within $1.5 \mathrm{~h}$ which is faster than the conventional ELISA kits $(\sim 3 \mathrm{~h})$. The assay also showed a linear relationship from 0.1 to $100 \mathrm{ng} / \mathrm{mL}$ for AFP with a lower LOD which is two orders of magnitude lower than the threshold for the human serum $(10 \mathrm{ng} / \mathrm{mL})$. Here the measurements were also done at $10 \mathrm{mV}$ at $100 \mathrm{kHz}$ similar to the previous study [58]. The sensor indicated an intra batch reproducibility with a coefficient of variance $(\mathrm{CV})$ of $8.7 \%$ for $1 \mathrm{ng} / \mathrm{mL}$ and inter batch reproducibility with a CV of $10.9 \%$ for $1 \mathrm{ng} / \mathrm{mL}$ AFP.

Nanoparticles enhanced the sensitivity of the conductometric sensor by approximately 6 times as compared to the best sensitivity reported for the above described metal electrodes $(5.58 \mu \mathrm{S} / \mu \mathrm{M})$ [57]. Addition of nanoparticles facilitate a versatile platform to immobilize different protein to perform various immunoassays $[21,58]$. Four out of eight $[21,55,57,58]$ studies discussed here have reported the interference test and tested the sensors with real samples.

\subsection{Conductometric Sensors Using Other Materials}

$\mathrm{SnO}_{2}$ with a band gap of $3.2 \mathrm{eV}$ (room temperature) is widely used in gas sensors. The $\mathrm{SnO}_{2}$ layer is sensitive to $\mathrm{H}_{2} \mathrm{O}_{2}$ through adsorption of molecular oxygen (Reaction 3). The detailed sensing mechanism of $\mathrm{SnO}_{2}$ electrodes is described in Section 3.3. Here, a low-cost flexible and one-time use sensor was prepared using cellulose and $\mathrm{SnO}_{2}$ for glucose detection [59] (Figure 6d). The regenerated cellulose substrate was spin coated onto a silicon substrate and cured. $\mathrm{SnO}_{2}$ was deposited on top of the regenerated cellulose film by leaving the substrate immersed in the $\mathrm{SnO}_{2}$ solution for a given time. An increase in immersion time results in an increase in current which may be due to an increase in the amount of $\mathrm{SnO}_{2}$ crystals grown over time, thus improving the crystallinity of the grown layer. GOD was immobilized by physisorption when the cellulose-SnO $\mathrm{S}_{2}$ substrate was left in the glucose solution for $16 \mathrm{~h}$. The fabricated sensor exhibited a linear response from $0.5-12 \mathrm{mM}$ of glucose concentrations when measurements were performed in phosphate buffer at $\mathrm{pH}$ 7.2. The sensor offers a low-cost alternative to enzyme based $\mathrm{H}_{2} \mathrm{O}_{2}$ sensors. 
However, it has a limited measuring range and required a high potential (up to 3V) for detection, which could lead to interference with other coexisting compounds present in the analyte.

\section{FET Sensors}

$\mathrm{H}_{2} \mathrm{O}_{2}$ is not an ideal molecule to detect using electrochemical reactions due to its slow reaction kinetics. Amperometric sensors overcome this by applying a suitable potential to accelerate the reaction kinetics. However, this overpotential limits the detection at low concentrations because of a high signal to noise ratio. Similar detection limit issues exist for potentiometric sensors. In FET sensors, the phenomenon of surface charging at the gate and the effect of it on the inversion layer created and the conductivity of the channel is non-linear and hence the amplification can result. FET sensors can be classified in to four major groups based on the active material used for the detection: silicon nitride [40-42,45,46,60-62], conducting polymers [63-67], metal oxide [44,68-74], and carbon nanomaterials $[24,25,75-79]$. The sensors are evaluated based on crucial parameters like measuring range, sensitivity, detection limit, and response time. FET sensors are summarized in Table 3.

\subsection{FET Sensors Based on Silicon Nitride}

Silicon nitride $\left(\mathrm{Si}_{3} \mathrm{~N}_{4}\right)$ has been widely used as a $\mathrm{pH}$ sensitive material for FETs due to its wide range of $\mathrm{pH}$ detection ( $\mathrm{pH} 2$ to 10$)$ and good sensitivity $(52-54 \mathrm{mV} / \mathrm{pH})$. The $\mathrm{pH}$ response of the $\mathrm{Si}_{3} \mathrm{~N}_{4}$ film coupled with enzymes like HRP that induce $\mathrm{pH}$ changes in the presence of $\mathrm{H}_{2} \mathrm{O}_{2}$ have been used in sensing. For instance, HRP [41,60] and electrochemical reduction using platinum electrodes [46] was used for direct $\mathrm{H}_{2} \mathrm{O}_{2}$ measurements. In contrast, GOD [40,42,45], invertase, and mutarotase [42] were used for detection of glucose and sucrose by converting these compounds into $\mathrm{H}_{2} \mathrm{O}_{2}$ and electrochemically reducing the $\mathrm{H}_{2} \mathrm{O}_{2}$ to generate protons for detection by the $\mathrm{Si}_{3} \mathrm{~N}_{4}$ film.

The earliest FET $\mathrm{H}_{2} \mathrm{O}_{2}$ sensor was constructed by immobilizing $\mathrm{HRP}$ on a $\mathrm{Si}_{3} \mathrm{~N}_{4}$ film, and a reference FET was also fabricated without any enzyme in the immobilized layer. The reduction of $\mathrm{H}_{2} \mathrm{O}_{2}$ using HRP is a three-step reaction. The first step involves the reduction of $\mathrm{H}_{2} \mathrm{O}_{2}$ while $\mathrm{HRP}$ is simultaneously oxidized. A mediator is used to convert the oxidized HRP back to its reduced form [41,75]. The working mechanism of HRP enzyme is shown below:

$$
\begin{gathered}
\mathrm{H}_{2} \mathrm{O}_{2}+\mathrm{HRP}(\text { red }) \rightarrow \mathrm{HRP}(\text { oxd })+2 \mathrm{H}_{2} \mathrm{O} \\
\mathrm{HRP}(\text { oxd })+\mathrm{M}+\mathrm{H}^{+} \rightarrow \mathrm{HRP}^{*}+\mathrm{M}^{+} \\
\mathrm{HRP}^{*}+\mathrm{M}+\mathrm{H}^{+} \rightarrow \mathrm{HRP}(\text { red })+\mathrm{M}^{+}
\end{gathered}
$$

HRP based sensors used reducing agents like potassium iodide [41], potassium hexacyanoferrate (II) [41] and ascorbic acid [60]. In 1994, a study evaluated the sensitivity of the Enzyme FET (ENFET) using two reducing substrates: potassium hexacyanoferrate (II) and potassium iodide (KI) [41]. An increase in linear range was observed with increase in the concentration of reducing agents. With KI, the sensor exhibited a better sensitivity, but the measuring range was narrower in case of hexacyanoferrate. The reusable biosensor showed an activity loss of $>10 \%$ after 1000 measurements. The detection range of the sensor was $5 \mu \mathrm{M}$ to $2 \mathrm{mM}$ at pH 6 with a LOD at $5 \mu \mathrm{M}$ and a sensitivity of $15 \mathrm{mV} / \mathrm{mM}$. The sensor had a response time of 30-90 s.

$\mathrm{H}_{2} \mathrm{O}_{2}$ ISFETs have been coupled with GOD to detect glucose (Reactions 10 and 11) $[40,42,45,46,61,62]$. Conventionally, these ISFETs used to target the protons generated from the dissociation of gluconic acid in solution (Reaction 11). However, the sensitivity of the sensors was limited by the low dissociation constant (pKa 3.8) of gluconic acid [80]. To increase the sensitivity, the researchers used the generated $\mathrm{H}_{2} \mathrm{O}_{2}$ to produce two additional hydrogen ions (Reaction 12). This facilitates the increase in sensitivity of the ISFET. In 
1996, the first study demonstrated the feasibility of using $\mathrm{H}_{2} \mathrm{O}_{2}$ electrolysis to increase the sensitivity of a glucose ISFET [40].

$$
\begin{aligned}
\mathrm{C}_{6} \mathrm{H}_{12} \mathrm{O}_{6}+\mathrm{H}_{2} \mathrm{O} & +\mathrm{O}_{2} \stackrel{\mathrm{GOD}}{\rightarrow} \mathrm{C}_{6} \mathrm{H}_{12} \mathrm{O}_{7}+\mathrm{H}_{2} \mathrm{O}_{2} \\
\mathrm{C}_{6} \mathrm{H}_{12} \mathrm{O}_{7} & \leftrightarrow \mathrm{C}_{6} \mathrm{H}_{11} \mathrm{O}_{7}^{-}+\mathrm{H}^{+} \\
\mathrm{H}_{2} \mathrm{O}_{2} & \rightarrow 2 \mathrm{H}^{+}+\mathrm{O}_{2}+2 \mathrm{e}^{-}
\end{aligned}
$$

Apart from the analyte present, the availability of oxygen in the solution also determines the response as seen from reaction 10 . The regeneration of oxygen by decomposition of the generated $\mathrm{H}_{2} \mathrm{O}_{2}$ (Reaction 12) through electrochemical means can serve to enhance the signal obtained from the catalysis of glucose by GOD (Reaction 10). The additional oxygen would also facilitate glucose measurement over a wider range. The electrolysis of $\mathrm{H}_{2} \mathrm{O}_{2}$ was facilitated using a platinum electrode and applying a $0.65 \mathrm{~V}$ bias to the electrode. This method also established the baseline of the sensor which is critical for reliable measurements using FETs due to the high inherent drift rates $(0.1-1 \mathrm{mV} / \mathrm{h})$. In conventional methods, the baseline was established by introducing a glucose free solution before the measurement. However, this method established the baseline by removing the potential bias which alleviates the need of a glucose free solution.

With no potential bias, the upper limit of measurement was $1.5 \mathrm{mM}$ which is due to limited oxygen availability for reaction 11 . With potential bias, the upper limit was increased to $5 \mathrm{mM}$ from $1.5 \mathrm{mM}$ (no potential bias) which is due to additional oxygen generated by reaction 12 . The sensitivity of the sensor was $\sim 40 \mathrm{mV} / \mathrm{mM}$ in a $5 \mathrm{mM}$ phosphate buffer and $17 \mathrm{mV} / \mathrm{mM}$ in a $20 \mathrm{mM}$ phosphate buffer which is similar to the first sensor $(\sim 15 \mathrm{mV} / \mathrm{mM})$. The reduction in sensitivity was observed, when the buffer strength is increased from $5 \mathrm{mM}$ to $20 \mathrm{mM}$ due to the facilitated diffusion of protons from the enzyme layer to the bulk at higher buffer concentrations. Further, the response time of the sensor was around $8 \mathrm{~min}$ which was higher than the first sensor $(<1.5 \mathrm{~min})$ [41].

The ISFET glucose sensor still had a slower response time which was dealt in a later study by reducing the thickness of the enzyme layer on top of the gate [42]. The sensor was coated with multiple enzymes (invertase and mutarotase) to detect sucrose. Invertase breaks down the sucrose molecule to $\alpha$-D-glucose and fructose (Reaction 13). $\alpha$-D-glucose was converted to $\beta$-D-glucose using mutarotase (Reaction 14), and then the detection was done using a glucose ISFET sensor (Reactions 10-12).

$$
\begin{aligned}
& \text { Sucrose } \stackrel{\text { Invertase }}{\longrightarrow} \alpha-\mathrm{D}-\text { glucose }+ \text { fructose } \\
& \alpha-\mathrm{D}-\text { glucose } \stackrel{\text { Mutarotase }}{\longrightarrow} \beta-\mathrm{D}-\text { glucose }
\end{aligned}
$$

A thin photopolymer (Polyvinyl alcohol-Styrylpyridinium) membrane was spin coated on top of the $\mathrm{Si}_{3} \mathrm{~N}_{4}$ layer. The glucose ISFET exhibited a linear range from 1.67-16.67 mM with a response time of less than $5 \mathrm{~min}$. The platinum electrode also had a significant effect on the sensitivity of the sensor. With increasing platinum electrode area, the sensitivity of the ISFET increases due to an increase in the number of protons generated in the vicinity of the $\mathrm{pH}$-gate. However, a detailed study of the platinum electrode area with respect to the area of the gate needs to be done before establishing any direct relationship between the two factors. A similar ENFET was proposed to detect glucose using platinum electrodes on top of the gate of the ISFET $[45,81]$. The study proposed a ladder like platinum electrode designed to further improve the sensitivity and measuring range of the sensor (Figure 7a). The polarization potential was also investigated by a later study using cyclic voltammetry [46]. The GOD and lactate oxidase were immobilized on the sensor for detection of glucose and lactate, respectively. $\mathrm{Si}_{3} \mathrm{~N}_{4}$ has advantages like good $\mathrm{pH}$ sensitivity, a wide $\mathrm{pH}$ working range and a simple manufacturing process which needs one additional deposition step for device fabrication. 
(a)

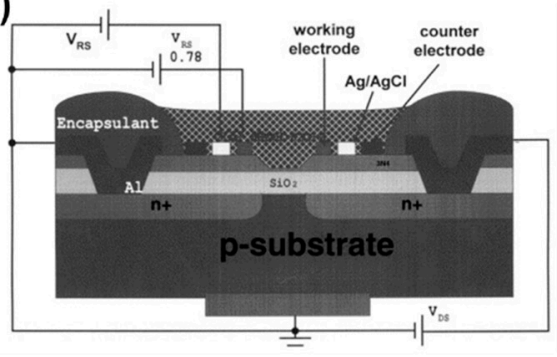

(d)

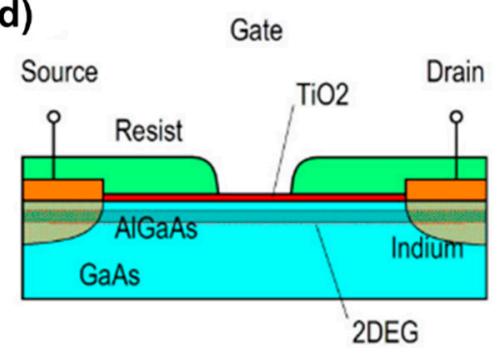

(b)

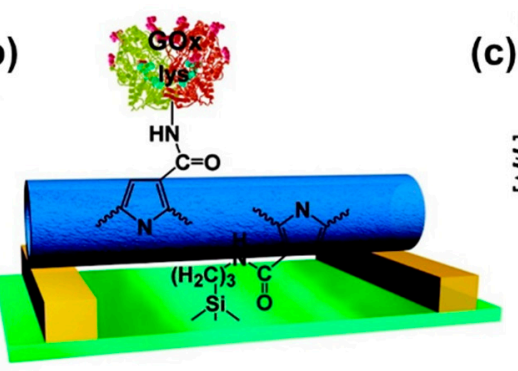

(c)

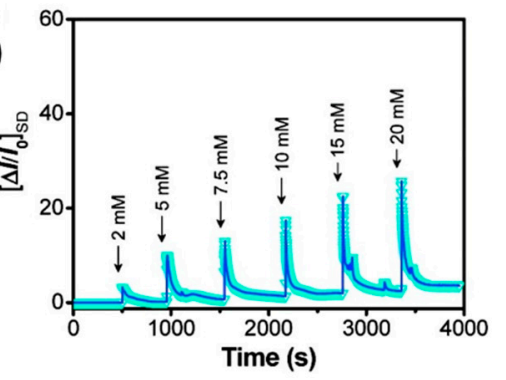

(e) $\mathrm{H}_{2} \mathrm{O}_{2}$

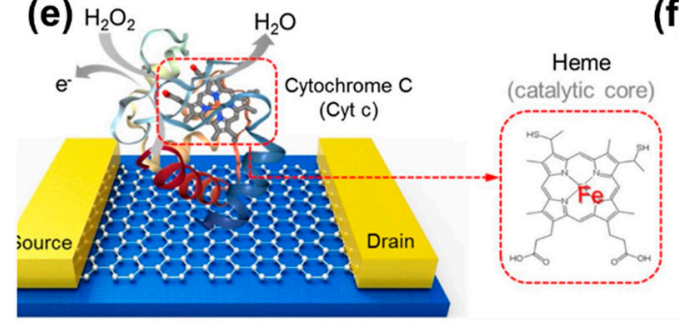

(f)

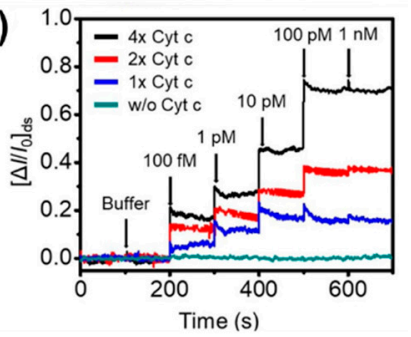

Figure 7. (a) A solid ISFET glucose sensor with a ladder-type platinum electrode as the working electrode, a counter electrode and an $\mathrm{Ag} / \mathrm{AgCl}$ reference electrode. Reprinted from [75] with permission from Elsevier. (b) GOD-Carboxylated Polypyrrole nanotubes FET sensor for detection of $\mathrm{H}_{2} \mathrm{O}_{2}$ and glucose. Reprinted (adapted) with permission from [57]. Copyright 2008 American Chemical Society. (c) Real time current response due to of the sensor described in Figure $7 \mathrm{~b}$ when it is exposed to $\mathrm{H}_{2} \mathrm{O}_{2}$ ranging from 2-20 mM. Reprinted (adapted) with permission from [57]. Copyright 2008 American Chemical Society. (d) A TiO 2 thin film FET to monitor the cell viability with $\mathrm{H}_{2} \mathrm{O}_{2}$ as the marker. Reprinted with permission from [64]. (e) Schematics of a cytochrome-c (cyt c) based ultrasensitive $\mathrm{H}_{2} \mathrm{O}_{2}$ sensor. Reprinted from [73] with permission from Elsevier. (f) Plot showing the stepped current response, when the sensor is exposed to various concentration of $\mathrm{H}_{2} \mathrm{O}_{2}$ (0.1 pM to $1 \mathrm{nM}$ ), while different color solid line represents the cytochrome-c loading on the sensor no cyt $\mathrm{c}$ (green), $1 \times$ cyt c(blue), $2 \times$ cyt c(red) and $4 \times$ cyt c (black). Reprinted from [73] with permission from Elsevier.

\subsection{FET Sensors Based on Conducting Polymers}

Conducting polymers are used to fabricate sensors due to their ability to readily undergo oxidation and reduction, simple polymerization, reproducible deposition, and their stability in aqueous solutions. Common conducting polymers used in FET sensors are polyaniline $[61,75,76,82]$, polypyrrole [65-67] and poly(3,4ethylenedioxythiophene) (PEDOT) $[63,64,83-86]$.

\subsubsection{Polyaniline}

Some of the initial conducting polymer based $\mathrm{H}_{2} \mathrm{O}_{2}$ sensors were constructed using polyaniline $[61,75,76]$ due to its two distinctive properties. Firstly, the polymer has two conducting/insulating transitions induced by electrochemical oxidation: leucoemeraldine (insulating) to emeraldine (conducting); further oxidation of emeraldine to pernigraniline (insulating). Second, only the protonated form of emeraldine is conductive. Therefore, the conductivity of polyaniline can be changed either by changing the $\mathrm{pH}$ of the solution or in the presence of a redox species in the solution $[87,88]$. One example was a sensor using $\mathrm{HRP}$ as enzyme that catalyzes the conversion of $\mathrm{H}_{2} \mathrm{O}_{2}$ (detailed reactions in Section 5.1). This study was the first to demonstrate the use of a HRP-polyaniline based enzyme switch to measure $\mathrm{H}_{2} \mathrm{O}_{2}$ [75]. Polyaniline was grown on carbon electrodes with silver paint as the electrical contacts. In the study, polyaniline acts as the electron donor without any external mediator for the electron transfer. It was proven that the response is due to the oxidation of the polyaniline instead of other changes such as $\mathrm{pH}$, which are typical in enzyme catalyzed reactions. The response of the device can be measured using both switching time and switching ratio. The device was calibrated using a single point calibration method to measure unknown concentrations. The devices measured the $\mathrm{H}_{2} \mathrm{O}_{2}$ concentration with 
an error of $0.03 \mathrm{mM}$ within a $95 \%$ confidence interval. However, the device can only measure $\mathrm{H}_{2} \mathrm{O}_{2}$ concentrations below $0.5 \mathrm{mM}$. This was because the sensor response was inhibited at higher $\mathrm{H}_{2} \mathrm{O}_{2}$ due to formation of oxyperoxidase, a relatively stable form of the HRP enzyme. The sensor showed a response time of $100 \mathrm{~s}$ and a LOD of $\sim 0.2 \mathrm{mM}$. The polyaniline film was reset electrochemically by reducing the film. However, the residual oxyperoxidase form of HRP posed a serious problem for repeatable use.

Polyaniline films are also doped by anions like bisulphates and chlorides. At $\mathrm{pH}>5$, the deprotonation of the emeraldine form results in an insulating polyaniline layer which limits its application in physiological settings. The deprotonation is accompanied by the removal of anions like bisulphates and chlorides [89]. These small anions can be substituted with long chain polymeric anions like poly (aniline-co-N-propane sulfonic acid aniline) (PSPANI) [76] or poly (acrylic acid) (PAA) [61] to prevent the deprotonation of polyaniline at neutral $\mathrm{pH}$. Raffa et al. modified polyaniline to prepare poly(aniline-co-N-propane sulfonic acid aniline) (PSPANI) [76]. The polymer exhibited a good conductivity at $\mathrm{pH}$ 7. The sensor was prepared by modifying PSPANI with HRP to detect $\mathrm{H}_{2} \mathrm{O}_{2}$. The FET worked within a range of $0.025-1 \mathrm{mM}$ with a response time of $100-300 \mathrm{~s}$. The switching rate of the sensors was $0.126 \mu \mathrm{A} / \mathrm{s}$. Another study used PAA to maintain the polyaniline conductivity at near neutral $\mathrm{pH}$ [61]. Here, the polyaniline was modified during the electropolymerization to generate a hybrid film. GOD was immobilized on the PANI-PAA film for specific detection of glucose within a range from $0-9 \mathrm{mM}$ which was a significant improvement from the previous polyaniline $\mathrm{H}_{2} \mathrm{O}_{2}$ FET sensors. The sensor had a rapid response time of $<1 \mathrm{~s}$ with a sensitivity of $1 \mathrm{nA} / \mathrm{mM}$. Although multiple FET sensors are constructed using polyaniline, they have a few limitations, such as conductivity degradation at elevated $\mathrm{pH}$ conditions, hysteresis, and limited shelf life. Further details are discussed in this review [90].

\subsubsection{Polypyrrole}

Polypyrrole is popular as a sensing material due to its good conductivity $(10-100 \mathrm{~S} / \mathrm{cm})$, temperature stability, and ambient air storage stability with no significant changes in conductivity for at least 2 weeks [91]. Polypyrrole nanotubes have been used for detection of $\mathrm{H}_{2} \mathrm{O}_{2}$ as well as other analytes like glucose [65-67]. For example, a study reported a liquid gated FET sensor based on GOD functionalized polypyrrole nanotubes [65]. Carboxylated polypyrrole nanotubes enabled high enzyme loading on the sensor surface due to their high surface area and high density of surface functionalization groups (Figure 7b). Upon glucose addition, the current increased due to $\mathrm{H}_{2} \mathrm{O}_{2}$ generated from the reaction of glucose with GOD which changes the charge transfer characteristics of the polymer. Then, it gradually decreased due to deprotonation of the conducting polymer by the positive gate potential (Figure $7 \mathrm{c}$ ). The sensor showed a $\sim 3.75 \%$ current change per $\mathrm{mM}$ of glucose concentration relative to the baseline current when the sensor was not exposed to glucose. The measuring range was from $2-20 \mathrm{mM}$ with $0.5 \mathrm{mM}$ as the LOD. The sensor response time was 5-10 s. A different liquid gated FET was fabricated using a reduced graphene oxide(rGO) and polypyrrole nanotube composite [66]. The nanocomposite was created using the electrostatic interaction between positively charged polypyrrole nanotubes and negatively charged rGO. Individually, both rGO and nanotubes were sensitive to $\mathrm{H}_{2} \mathrm{O}_{2}$ concentration. Moreover, the composite exhibited a better sensitivity due to increased surface area, strong interactions between rGO and polypyrrole nanotubes, and improved signal transduction attributed to enhanced semiconductor behavior of the composite. The sensor extended a LOD of $0.1 \mathrm{nM}$ with a measuring range from $0.1 \mathrm{nM}$ to $100 \mathrm{nM}$. The sensor showed a sensitivity of $\sim 2 \%$ change/decade change of the $\mathrm{H}_{2} \mathrm{O}_{2}$ concentration with respect to the baseline. A fast response time, no significant interference from common interferents like ascorbic acid, uric acid, and glucose, and long-term storage stability (1 month in air) make the sensor a good candidate for real sample applications such as in the food industry or for environmental samples.

The rGO-polypyrrole nanotube composite sensor functionalized with GOD was also used to measure glucose concentrations in diluted human, bovine and horse serum samples 
in a subsequent study [67]. The sensor exhibited a wide measuring range from $1 \mathrm{nM}$ to $100 \mathrm{mM}$ with a detection limit of $1 \mathrm{nM}$. The sensor showed a better sensitivity of $\sim 5 \%$ change/decade which was 2.5 times better than the previous sensor [66]. The enzyme functionalization does not have any influence on the response time $(<1 \mathrm{~s})$. The sensor also had the similar repeatability and storage stability (1 month in air).

\subsubsection{PEDOT}

PEDOT is a positively charged polymer commonly doped with polystyrene sulfonate (PSS), a negatively charged polymer. PEDOT: PSS is used to fabricate sensors with excellent stability and a wide range of operating $\mathrm{pH}$. Organic thin film transistors (OTFTs) have been fabricated using PEDOT: PSS as the conducting polymer due to its ability to form stable thin films with sufficient conductivity [63,64,83-86]. OTFTs rely on electrostatic gating based on electrochemical doping or de-doping of the conducting polymer film and electrolyte solution. The conductivity of these devices is modulated by gate voltage. The sensing mechanism of the device can be explained by two mechanisms: ion-leveraged [92] and electrochemical [93]. In the ion-leveraged mechanism, the positive charge present in the solution migrates to the PEDOT: PSS film and changes its conductivity by disrupting the tunneling of holes in the film. In the electrochemical mechanism, $\mathrm{H}_{2} \mathrm{O}_{2}$ gets oxidized at the gate electrode and the charge balance is maintained by the reduction of PEDOT in the conducting polymer film. $\mathrm{Y}^{+}$represents the positively charged ions present in the solution (Reaction 15).

$$
\mathrm{PEDOT}^{+}: \mathrm{PSS}^{-}+\mathrm{Y}^{+}+\mathrm{e}^{-} \leftrightarrow \mathrm{PEDOT}^{+} \mathrm{Y}^{+}: \mathrm{PSS}^{-}
$$

These devices need low operating voltages, low-cost substrate, low processing temperatures, and have simple structures which makes them easy to manufacture and integrate in microfluidic chips. In one example of a PEDOT:PSS-GOD based OTFT, a gate voltage was applied to measure glucose concentrations in a buffered solution [83]. The change in glucose concentration was measured using the change in drain-source current. The GOD converted glucose to gluconic acid and hydrogen peroxide. The generated $\mathrm{H}_{2} \mathrm{O}_{2}$ is oxidized at the platinum gate electrode which results in a change in drain-source current. The sensor exhibited a narrow measuring range from $0.1-1 \mathrm{mM}$ with a response time of $\sim 1$ min. Similar sensors were reported in other studies with improved response time and measuring range [63,64,84-86]. Another study has used GOD in a PEDOT:PSS matrix to form the channel of the OTFT [64]. The sensor reported a wide range of detection from 1.1 to $16.5 \mathrm{mM}$ with a rapid response time of $20 \mathrm{~s}$. The sensitivity of the sensor of $1.65 \mu \mathrm{A} / \mathrm{mM}$ of glucose concentration and the detection limit of $\sim 1 \mathrm{mM}$ makes it suitable for blood glucose measurements. The TFT sensor was further modified by covalently immobilizing the enzyme on the sensing layer using methacrylate polymer chains [86]. The sensor exhibited a good enzyme activity with a wide measuring range $0.01-100 \mathrm{mM}$ for glucose and $0.01 \mathrm{mM}$ as the detection limit. However, the response time of the sensor was $\sim 360 \mathrm{~s}$ which was longer than for the previous sensors $[64,83]$. The sensor was stable for 100 days in storage with intermittent measurements. The detection range of the TFT sensors was extended to lower concentrations by using a $\mathrm{TiO}_{2}$ nanotube array and platinum nanoparticles as the gate electrode [85]. The sensor showed a wide measuring range from $0.001-5 \mathrm{mM}$ for $\mathrm{H}_{2} \mathrm{O}_{2}$.

\subsection{FET Sensors Based on Metal Oxides}

The sensitivity of ENFETs can be improved by oxidizing $\mathrm{H}_{2} \mathrm{O}_{2}$ through an applied external potential bias. However, in order to apply a potential, it is necessary to add an additional electrode on top of the gate of the FET. Therefore, some studies have used metal oxides as the catalyst to circumvent the need for an additional electrode. Metal oxides such as manganese dioxide $\left(\mathrm{MnO}_{2}\right)$ [62,68], iridium oxide [69], lanthanide perovskite oxide [44], titanium oxide $\left(\mathrm{TiO}_{2}\right)$ [71], iron (III) oxide $\left(\mathrm{Fe}_{2} \mathrm{O}_{3}\right)$ [72], and zinc oxide $(\mathrm{ZnO})$ [74,94] were used to catalyze the oxidation of $\mathrm{H}_{2} \mathrm{O}_{2}$. One of the earliest metal oxides used was $\mathrm{MnO}_{2}$, 
which catalyzed the conversion of $\mathrm{H}_{2} \mathrm{O}_{2}$ into $\mathrm{H}_{2} \mathrm{O}$ and $\mathrm{O}_{2}$ through a sequence of steps (Reactions 16-19) [68,95].

$$
\begin{gathered}
\mathrm{MnO}_{2}+\mathrm{H}_{2} \mathrm{O} \rightarrow \mathrm{MnO}(\mathrm{OH})_{2} \\
\mathrm{MnO}(\mathrm{OH})_{2} \rightarrow \mathrm{MnO}^{2+}+2 \mathrm{OH}^{-} \\
\mathrm{MnO}^{2+}+\mathrm{H}_{2} \mathrm{O}_{2}+4 \mathrm{OH}^{-} \rightarrow \mathrm{MnO}_{4}^{2-}+3 \mathrm{H}_{2} \mathrm{O} \\
\mathrm{MnO}_{4}^{2-}+\mathrm{H}_{2} \mathrm{O} \rightarrow \mathrm{MnO}_{2}+0.5 \mathrm{O}_{2}+2 \mathrm{OH}^{-}
\end{gathered}
$$

The first study to use $\mathrm{MnO}_{2}$ as catalyst for $\mathrm{H}_{2} \mathrm{O}_{2}$ conversion utilized a $\mathrm{H}^{+}$sensitive ENFET covered with a manganese dioxide $\left(\mathrm{MnO}_{2}\right)$ doped Bovine serum albumin (BSA) membrane [68]. This outer membrane used $\mathrm{MnO}_{2}$ powder to catalyze the conversion of $\mathrm{H}_{2} \mathrm{O}_{2}$ to $\mathrm{H}_{2} \mathrm{O}$ and $\mathrm{O}_{2}$. The detection limit of the sensor was $2.7 \mathrm{mM}$ with a response time of $12 \mathrm{~min}$. The sensitivity of the sensor was estimated to $2.35 \mathrm{mV} / \mathrm{mM}$ of glucose concentration within a measuring range up to $20 \mathrm{mM}$. The $\mathrm{MnO}_{2}-\mathrm{BSA}$ membrane facilitated the diffusion of extra oxygen required by GOD resulting in a wider linear dynamic range. The oxidizing ability of $\mathrm{MnO}_{2}$ strongly depends on the $\mathrm{pH}$ range and increases with an increase in $\mathrm{pH}$. In contrast, the stability of GOD decreases with $\mathrm{pH}$. Therefore, the sensor response was highest at $\mathrm{pH} 8.1$ and it decreases at higher $\mathrm{pH}$ values. Another study further modified the ENFET using $\mathrm{MnO}_{2}$ nanoparticles to increase the dynamic range and reduce the response time. An increase in $\mathrm{pH}$ is observed when $\mathrm{MnO}_{2}$ nanoparticles were used instead of bulk $\mathrm{MnO}_{2}$ particles. Therefore, a new mechanism was proposed to explain the $\mathrm{pH}$ increase (Reactions 20-23) [62].

$$
2 \mathrm{MnO}_{2}+\mathrm{H}_{2} \mathrm{O}_{2} \rightarrow 2 \mathrm{MnOOH}+\mathrm{O}_{2}
$$

$\mathrm{MnOOH}$ can undergo disproportionation (Reaction 23) or reduction (Reaction 22).

$$
\begin{gathered}
2 \mathrm{MnOOH}+\mathrm{H}_{2} \mathrm{O}_{2}+4 \mathrm{H}^{+} \rightarrow 2 \mathrm{Mn}^{2+}+4 \mathrm{H}_{2} \mathrm{O}+\mathrm{O}_{2} \\
2 \mathrm{MnOOH}+2 \mathrm{H}^{+} \rightarrow \mathrm{MnO}_{2}+\mathrm{Mn}^{2+}+2 \mathrm{H}_{2} \mathrm{O} \\
\mathrm{C}_{6} \mathrm{H}_{12} \mathrm{O}_{6}+\mathrm{MnO}_{2}+\mathrm{H}^{+} \stackrel{\mathrm{GOD}}{\longrightarrow} \mathrm{C}_{6} \mathrm{H}_{12} \mathrm{O}_{7}+\mathrm{H}_{2} \mathrm{O}+\mathrm{Mn}^{2+}
\end{gathered}
$$

The sensor showed a wider range of detection from $0.025-1.9 \mathrm{mM}$ and the response time was reduced to $140 \mathrm{~s}$ from $\sim 12 \mathrm{~min}$ (for bulk $\mathrm{MnO}_{2}$ particles) [68]. The sensitivity of the sensor can be estimated as $\sim 10 \mathrm{mV} / \mathrm{mM}$. The nanoparticle sensor enhanced the sensitivity as compared to bulk oxide $\mathrm{MnO}_{2}$ particles $(\sim 2.35 \mathrm{mV} / \mathrm{mM})$. The detection limit was also extended to the lower $\mathrm{H}_{2} \mathrm{O}_{2}$ concentrations but the upper detection was limited to $1.9 \mathrm{mM}$ as opposed to $20 \mathrm{mM}$ for bulk $\mathrm{MnO}_{2}$ particles [68].

In a later study, three different $\mathrm{H}_{2} \mathrm{O}_{2}$ sensitive materials: $\operatorname{Ir}(\mathrm{OH})_{3}$, Prussian blue and a polyvinyl pyridine membrane containing HRP-Osmium, were investigated as functional catalyst materials [69]. Iridium hydroxide was the most stable catalyst even though it has the lowest catalytic activity. However, it can be used over a broad $\mathrm{pH}$ range (3.5-9) for detection of high concentrations of $\mathrm{H}_{2} \mathrm{O}_{2}(0.1 \mathrm{mM}$ to $0.1 \mathrm{M})$ with a sensitivity of $400 \mathrm{mV}$ / decade of concentration change. Prussian blue has a medium catalytic activity and the lowest sensitivity $(290 \mathrm{mV} /$ decade) among all three tested materials. It can operate in a $\mathrm{pH}$ range of 4.5-6 for detection of $\mathrm{H}_{2} \mathrm{O}_{2}$ concentrations from 0.01 to $1 \mathrm{mM}$. HRP with Osmium as the mediator possesses the highest catalytic activity and highest sensitivity ( $700 \mathrm{mV} /$ decade) but it is less stable compared to both of the more sensitive materials. Nevertheless, it can only operate in a narrow $\mathrm{pH}$ range of 6.5-7.5 for the detection of low concentrations of $\mathrm{H}_{2} \mathrm{O}_{2}(0.1$ to $10 \mu \mathrm{M})$. Another study reported a lanthanide perovskite oxide based FET sensor where the perovskite worked as a catalyst for $\mathrm{H}_{2} \mathrm{O}_{2}$ decomposition due to the presence of oxygen vacancies [44]. Tantalum oxide was used as the gate electrode. The sensitivity of the sensor was $35 \mathrm{mV} /$ decade within a measuring range of $0.005-0.2 \mathrm{mM}$. The response time of the sensor was around $30 \mathrm{~min}$ which was higher than the other metal 
oxide sensors [62,68] The detection limit of the sensor was around $4 \mu \mathrm{M}$ which can be extended by changing the stoichiometry of the perovskite oxide.

Another study utilized a biocompatible thin film FET sensor for assessing the cell viability in the culture [71] through peroxide detection (Figure 7d). A $\mathrm{TiO}_{2}$ thin film was used due its biocompatibility and minimal cell adhesion [96]. The chances of cell survival are reduced with the increase in $\mathrm{H}_{2} \mathrm{O}_{2}$ concentration. So, it can serve as a good indicator for cell viability. The sensitivity of the FET was strongly dependent on the testing medium. A sensitivity of $4.5 \mathrm{mV} / \mu \mathrm{M}$ was observed in Dulbecco's Modified Eagle medium while a 10 times reduction was observed in phosphate buffer $(0.41 \mathrm{mV} / \mu \mathrm{M})$. The response time of the sensor was $5 \mathrm{~min}$.

Nanorods have also used to increase the signal to noise ratio and to enhance the sensitivity of the FET based sensors. $\mathrm{ZnO}$ nanorods were used to fabricate efficient electrodes for applications like device fabrication drug delivery, and others. Using $\mathrm{ZnO}$ nanorods, a multiplex FET was constructed to detect three analytes: glucose, cholesterol, and urea (urea sensor was not discussed here as it was not linked to $\mathrm{H}_{2} \mathrm{O}_{2}$ ) [74]. In the presence of respective oxidases, glucose and cholesterol generate $\mathrm{H}_{2} \mathrm{O}_{2}$ which produces changes to the charge transfer properties of the $\mathrm{ZnO}$ film resulting in the sensor signal. The sensor response was linear from $0.05-70 \mathrm{mM}$ and $0.01-45 \mathrm{mM}$ for glucose and cholesterol, respectively. The sensitivity of the sensor was $32.27 \mu \mathrm{AmM}^{-1} \mathrm{~cm}^{-2}$ and $17.1 \mu \mathrm{AmM}^{-1} \mathrm{~cm}^{-2}$. The sensor response was tested in real samples like mouse blood and serum. The serum sample measurements were similar to buffered solution measurements, but the sensor response diminished by around $7 \%$ and $19 \%$ for glucose and cholesterol respectively in mouse blood. The sensor showed a stable response for 40 days with multiple measurements. Similarly, a non-enzymatic sensor was also constructed using $\mathrm{ZnO}$ nanorods coupled with $\mathrm{NiO}$ quantum dots [94]. $\mathrm{NiO}$ reacts with glucose to generate $\mathrm{H}_{2} \mathrm{O}_{2}$ and then $\mathrm{ZnO}$ nanorods can detect the generated $\mathrm{H}_{2} \mathrm{O}_{2}$ as described above. The sensor exhibited two linear ranges: one from $0.001-10 \mathrm{mM}$ with a sensitivity of $13.14 \mu \mathrm{A} / \mathrm{mM}$ and second from $10-50 \mathrm{mM}$ with almost half the sensitivity $(7.31 \mu \mathrm{A} / \mathrm{mM})$.

Multiple metal oxide bulk and nanomaterials can be deposited on the gates of FETs for $\mathrm{H}_{2} \mathrm{O}_{2}$ detection. $\mathrm{ZnO}$ nanoparticles are becoming more popular due to their high specific surface area, and efficient enzyme immobilization leading to a high sensitivity. Further, $\mathrm{ZnO}$ nanorod FETs showed a good response within the clinically relevant range in real samples like serum or blood. Therefore, $\mathrm{ZnO}$ can be a potential candidate for clinical applications.

\subsection{FET Sensors Based on Carbon Nanomaterials}

Carbon nanomaterials are widely used for fabricating biosensors due to their excellent mechanical and electrical properties. Various types of carbon based nanomaterials have been used to construct FET based sensors, such as CNTs [72,97], graphene [24,77-79,98,99], and reduced graphene oxide (r-GO) $[25,66,67,98]$. Several reviews have also been published on FETs constructed from carbon nanomaterials [100-102].

CNT are used in various sensors due to their smaller size (generally $1 \mu \mathrm{m}$ in length and 1-3 nm diameter), high surface sensitivity, chemical stability, good electrical conductivity, and high tensile strength [100]. However, the use of CNT in sensors faces challenges such as low dispersion in common solvents like water; and separation of semiconducting CNT from metallic CNT, which are good for sensing applications [103]. Recent studies have used dispersants like polymers [97], surfactants, and green tea [104]. Only a few examples exist where CNT sensors have been used in the detection of $\mathrm{H}_{2} \mathrm{O}_{2}$. A study reported the use of EGCG combined with CNT to fabricate a $\mathrm{H}_{2} \mathrm{O}_{2}$ sensitive FET sensor [72]. The measuring range of the sensor was from $10^{-5}$ to $10^{-3} \mathrm{M}$ with a detection limit of $<5 \mu \mathrm{M}$. The response time of the sensor was $\sim 500 \mathrm{~s}$.

Graphene, a single 2D sheet of carbon, has strengths such as high surface to volume ratio, and a flat surface resulting in easy and effective surface functionalization. Chemical vapor deposition (CVD) can be used to produce large graphene sheets which offers ad- 
vantages like uniform binding and better control over the surface modifications with $\pi-\pi$ interactions [98]. CVD grown graphene is also easier to integrate with contacts and finds use in sensors for detection of various analytes through the detection of $\mathrm{H}_{2} \mathrm{O}_{2}$. For example, a FET was fabricated using CVD grown graphene functionalized with GOD to detect glucose [77]. GOD was functionalized on the graphene film by pyrene butanoic acid succinimidyl ester. The linker used the pyrene group for $\pi-\pi$ interaction with the graphene surface and an amide bond on the other end with GOD. The catalytic activity of GOD resulted in an increase in graphene layer conductance leading to the sensor response.

Table 3. Summary of various FETs used for $\mathrm{H}_{2} \mathrm{O}_{2}$ measurement where OC: operating conditions; PANI: Polyaniline; PAA: poly acrylic acid; pDAB: poly(1,2 diaminobenzene); HRP: Horseradish peroxidase; PVP: poly(4-vinylpyridine-co-styrene); MOSC: Metal oxide semiconductor capacitor; 3-aminopropyltriethoxysilane (APTES), PPyNT: Polypyrrole nanotube, Pt: Platinum, $\mathrm{I}_{\mathrm{s}}$ : source current, $\mathrm{V}_{\mathrm{ds}}$ : Drain potential with respect to source, $\mathrm{V}_{\mathrm{g}}$ : is gate voltage, $\mathrm{I}_{\mathrm{ds}}$ : current between drain and source, $\mathrm{V}_{\mathrm{d}}$ : Drain potential, $\mathrm{V}_{\mathrm{bias}}$ : potential bias applied between the Pt electrode and reference electrode, $\mathrm{I}_{\text {bias }}$ : current bias, pDAB: poly(1,2-diaminoben-zene), ITO: Indium titanium oxide, GluD: Glutamate dehydrogenase, UA: Uric acid, AA: Ascorbic acid and $\mathrm{MoS}_{2}$ : Molybdenum disulphide.

\begin{tabular}{|c|c|c|c|c|c|c|c|c|c|c|}
\hline Substrate & $\begin{array}{c}\text { Target } \\
\text { Analyte }\end{array}$ & $\begin{array}{l}\text { Ligand/ } \\
\text { Enzyme }\end{array}$ & $\begin{array}{l}\text { LOD } \\
(\mu \mathrm{M})\end{array}$ & Sensitivity & $\begin{array}{c}\text { Measuring } \\
\text { Range (mM) }\end{array}$ & OC & $\begin{array}{c}\text { Response } \\
\text { Time (s) }\end{array}$ & $\begin{array}{c}\text { Working pH } \& \\
\text { Buffer }\end{array}$ & Comments & Ref \\
\hline \multicolumn{11}{|c|}{ Silicon nitride FET } \\
\hline $\mathrm{Si}_{3} \mathrm{~N}_{4}$-FET & $\mathrm{H}_{2} \mathrm{O}_{2}$ & HRP & 5 & $\begin{array}{c}\sim 15 \\
\mathrm{mV} / \mathrm{mM} \\
\quad \text { (est.) }\end{array}$ & $<2$ & $\begin{array}{c}\mathrm{I}_{\mathrm{s}}: 300 \mu \mathrm{A} \\
\mathrm{V}_{\mathrm{ds}}: 2 \mathrm{~V}\end{array}$ & $30-90$ & $\begin{array}{c}\text { Buffer: } \\
\text { Phosphate (10 } \\
\text { mM) } \\
\text { Working pH: } 6\end{array}$ & $\begin{array}{c}<10 \% \text { reduction } \\
\text { in enzyme } \\
\text { activity after } \\
1000 \\
\text { measurements }\end{array}$ & [41] \\
\hline $\begin{array}{c}\mathrm{Si}_{3} \mathrm{~N}_{4}{ }^{-} \\
\mathrm{FET} / \mathrm{Pt} \\
\text { electrode }\end{array}$ & Glucose & GOD & NR & $\begin{array}{c}\sim 40 \\
\mathrm{mV} / \mathrm{mM}\end{array}$ & $<5$ & $\mathrm{~V}_{\text {bias }}: 0.64 \mathrm{~V}$ & $\sim 480$ & $\begin{array}{c}\text { Buffer: } \\
\text { Phosphate } \\
\text { (5-20 mM) } \\
\text { Working pH: } \\
\quad 7.4\end{array}$ & $\begin{array}{l}\text { Baseline } \\
\text { established by } \\
\text { removing the } \\
\text { potential bias }\end{array}$ & [40] \\
\hline $\begin{array}{c}\mathrm{Si}_{3} \mathrm{~N}_{4}^{-} \\
\mathrm{FET} / \mathrm{Pt} \\
\text { electrode }\end{array}$ & $\begin{array}{l}\text { Glucose } \\
\qquad \& \\
\text { sucrose }\end{array}$ & $\begin{array}{l}\text { GOD \& } \\
\text { Invertase- } \\
\text { mutarotase- } \\
\text { GOD }\end{array}$ & $\begin{array}{l}\sim 50 \\
(\mathrm{est})\end{array}$ & NR & $1.67-16.67$ & $\mathrm{~V}_{\text {bias }}: 0.7 \mathrm{~V}$ & $180-300$ & $\begin{array}{c}\text { Buffer: } \\
\text { Phosphate (10 } \\
\text { mM) } \\
\text { Working pH: } \\
7.4\end{array}$ & $\begin{array}{l}\text { Greater Pt area, } \\
\text { increases } \\
\text { sensitivity }\end{array}$ & [42] \\
\hline $\begin{array}{c}\mathrm{Si}_{3} \mathrm{~N}_{4}^{-} \\
\mathrm{FET} / \mathrm{Pt} \\
\text { electrode }\end{array}$ & Glucose & GOD & $\begin{array}{l}1000 \\
\text { (est.) }\end{array}$ & $\begin{array}{c}\sim 11 \\
\mathrm{mV} / \mathrm{mM} \\
\quad(\text { est. })\end{array}$ & $1-10$ & $\mathrm{~V}_{\text {bias }}: 0.7 \mathrm{~V}$ & $\sim 60$ & $\begin{array}{c}\text { Buffer: } \\
\text { Phosphate (10 } \\
\text { mM) } \\
\text { Working pH: } \\
7.4\end{array}$ & $\begin{array}{l}\text { Ladder shape } \\
\text { Pt electrode } \\
\text { was used for } \\
\text { potential bias }\end{array}$ & [45] \\
\hline $\mathrm{Si}_{3} \mathrm{~N}_{4}$-FET & $\mathrm{H}_{2} \mathrm{O}_{2}$ & $\mathrm{Pt}$ & 10000 & $5 \mathrm{mV} / \mathrm{mM}$ & $10-100$ & $\begin{array}{l}\mathrm{I}_{\mathrm{ds}}: 0.1 \mathrm{~mA} \\
\mathrm{~V}_{\mathrm{ds}}: \mathrm{IV}\end{array}$ & 300 & $\begin{array}{c}\text { Buffer: } \\
\text { Phosphate (100 } \\
\text { mM) } \\
\text { Working pH: } \\
7.2\end{array}$ & $\begin{array}{l}\text { Used for } \\
\text { glucose and } \\
\text { lactate }\end{array}$ & [46] \\
\hline \multicolumn{11}{|c|}{ Conducting polymers } \\
\hline Carbon & $\mathrm{H}_{2} \mathrm{O}_{2}$ & $\begin{array}{l}\text { PANI- } \\
\text { pDAB- } \\
\text { HRP }\end{array}$ & 100 & NR & $<0.5$ & $\begin{array}{l}\mathrm{V}_{\mathrm{g}}: 200 \mathrm{mV} \\
\mathrm{V}_{\mathrm{d}}: 20 \mathrm{mV}\end{array}$ & $\sim 100 \mathrm{~s}$ & $\begin{array}{l}\text { Buffer: citrate- } \\
\text { phosphate- } \\
\mathrm{Na}_{2} \mathrm{SO}_{4} \\
\text { Working pH: } 5\end{array}$ & $\begin{array}{l}\mathrm{HRP} \text { inhibition } \\
\text { at } \mathrm{H}_{2} \mathrm{O}_{2} \\
\text { concentration > } \\
0.5 \mathrm{mM} \text {. }\end{array}$ & [75] \\
\hline $\begin{array}{l}\text { Kapton- } \\
\text { Carbon }\end{array}$ & $\mathrm{H}_{2} \mathrm{O}_{2}$ & $\begin{array}{l}\text { PSPANI- } \\
\text { HRP }\end{array}$ & 25 & $0.126 \mu \mathrm{A} / \mathrm{s}$ & $0.025-1$ & $\begin{array}{c}\mathrm{V}_{\mathrm{g}}: 0 \mathrm{~V} \\
\mathrm{~V}_{\mathrm{d}}: 20 \mathrm{mV}\end{array}$ & $100-300 \mathrm{~s}$ & $\begin{array}{c}\text { Buffer: } \\
\text { HEPES-KNO }_{3} \\
(100 \mathrm{mM}) \\
\text { Working pH: } 7\end{array}$ & $\begin{array}{c}\text { Sultonation } \\
\text { improves the } \\
\text { PANI } \\
\text { conductivity at } \\
\text { pH } 7\end{array}$ & [76] \\
\hline $\mathrm{Si}_{3} \mathrm{~N}_{4}$-FET & Glucose & $\begin{array}{l}\text { PANI-PAA- } \\
\text { GOD }\end{array}$ & NR & $1 \mathrm{nA} / \mathrm{mM}$ & $0-9$ & $\begin{array}{c}\mathrm{V}_{\mathrm{g}}: 20 \mathrm{mV} \\
\mathrm{V}_{\mathrm{ds}}: 10 \mathrm{mV}\end{array}$ & $<1 \mathrm{~s}$ & $\begin{array}{c}\text { Buffer: } \\
\text { Mcllvaine } \\
\text { Working pH: } 5\end{array}$ & $\begin{array}{l}\text { PANI-PAA film } \\
\text { was deposition } \\
\text { by electropoly- } \\
\text { merization }\end{array}$ & [61] \\
\hline PEDOT-TFT & $\begin{array}{l}\mathrm{H}_{2} \mathrm{O}_{2} \& \\
\text { Glucose }\end{array}$ & GOD & 100 & NR & $0.1-1$ & $\begin{array}{c}\mathrm{V}_{\mathrm{d}}: 0.2 \mathrm{~V} \\
\mathrm{~V}_{\mathrm{g}}: 0-0.6 \mathrm{~V}\end{array}$ & $\sim 60 \mathrm{~s}$ & $\begin{array}{l}\text { Buffer: PBS } \\
\text { Working } \\
\text { pH: } 7.14\end{array}$ & $\begin{array}{l}\mathrm{pH} \\
\text { independent } \\
\text { response from } \\
\text { pH } 5 \text { to } 9\end{array}$ & [83] \\
\hline PEDOT-TFT & Glucose & GOD & 1 & $\begin{array}{c}0.1 \\
\mathrm{~V} / \text { decade }\end{array}$ & $<1$ & $\mathrm{~V}_{\mathrm{ds}}:-0.2 \mathrm{~V}$ & NR & $\begin{array}{c}\text { Buffer: PBS } \\
\text { (15 mM) } \\
\text { Working } \\
\text { pH: } 6.8\end{array}$ & $\begin{array}{l}\text { Sensitivity can } \\
\text { be improved by } \\
\text { increasing } \mathrm{Vg}\end{array}$ & [63] \\
\hline
\end{tabular}


Table 3. Cont.

\begin{tabular}{|c|c|c|c|c|c|c|c|c|c|c|}
\hline Substrate & $\begin{array}{c}\text { Target } \\
\text { Analyte }\end{array}$ & $\begin{array}{l}\text { Ligand/ } \\
\text { Enzyme }\end{array}$ & $\begin{array}{l}\text { LOD } \\
(\mu \mathrm{M})\end{array}$ & Sensitivity & $\begin{array}{c}\text { Measuring } \\
\text { Range (mM) }\end{array}$ & OC & $\begin{array}{l}\text { Response } \\
\text { Time (s) }\end{array}$ & $\begin{array}{c}\text { Working pH \& } \\
\text { Buffer }\end{array}$ & Comments & Ref \\
\hline PEDOT-TFT & Glucose & GOD & $<1000$ & $\begin{array}{c}1.65 \\
\mu \mathrm{A} / \mathrm{mM}\end{array}$ & 1.1 to 16.5 & $\begin{array}{c}\mathrm{V}_{\mathrm{ds}}:-1.5 \mathrm{~V} \\
\mathrm{~V}_{\mathrm{g}}: 0.0 \mathrm{~V}\end{array}$ & $10-20 \mathrm{~s}$ & NR & $\begin{array}{c}\text { Sensor was } \\
\text { encapsulated in } \\
\text { cellulose acetate } \\
\text { membrane }\end{array}$ & [64] \\
\hline $\begin{array}{l}\text { Liquid } \\
\text { gate-FET }\end{array}$ & $\begin{array}{l}\mathrm{H}_{2} \mathrm{O}_{2} \& \\
\text { Glucose }\end{array}$ & $\begin{array}{l}\text { PPyNT- } \\
\text { GOD }\end{array}$ & $\begin{array}{l}500 \\
\text { (est.) }\end{array}$ & $\begin{array}{c}3.75 \% / \mathrm{mM} \\
\text { (est.) }\end{array}$ & $2-20$ & $\begin{array}{c}\mathrm{V}_{\mathrm{ds}}:-0.01 \\
\mathrm{~V} \\
\mathrm{~V}_{\mathrm{g}}: 0.01 \mathrm{~V}\end{array}$ & $5-10 \mathrm{~s}$ & $\begin{array}{c}\text { Buffer: PBS (10 } \\
\text { mM) } \\
\text { Working } \\
\text { pH: } 7.0\end{array}$ & $\begin{array}{l}\text { High enzyme } \\
\text { loading was } \\
\text { achieved }\end{array}$ & [65] \\
\hline TFT & $\begin{array}{l}\mathrm{H}_{2} \mathrm{O}_{2} \& \\
\text { Glucose }\end{array}$ & $\begin{array}{l}\text { PEDOT- } \\
\text { GOD }\end{array}$ & 1 & $\begin{array}{c}0.79-3 \\
\mu \mathrm{A} / \mathrm{mM}\end{array}$ & $0.001-5$ & $\begin{array}{c}\mathrm{V}_{\mathrm{ds}}:-0.4 \mathrm{~V} \\
\mathrm{~V}_{\mathrm{g}}: 0.4 \mathrm{~V}\end{array}$ & $<20 s$ & $\begin{array}{c}\text { Buffer: PBS } \\
\text { Working } \\
\text { pH: } 7.4\end{array}$ & $\begin{array}{l}\text { Used as both } \\
\text { optical and } \\
\text { electrochemical }\end{array}$ & [84] \\
\hline TFT & Glucose & $\begin{array}{l}\text { PEDOT- } \\
\text { GOD }\end{array}$ & 10 & NR & $0.01-100$ & $\begin{array}{c}\mathrm{V}_{\mathrm{ds}}:-0.7 \mathrm{~V} \\
\mathrm{~V}_{\mathrm{g}}: 0.7 \mathrm{~V}\end{array}$ & $\sim 360 \mathrm{~s}$ & $\begin{array}{l}\text { Buffer: PBS } \\
(120 \mathrm{mM})\end{array}$ & $\begin{array}{l}\text { Stable for } 100 \\
\text { days with } \\
\text { covalently } \\
\text { immobilized } \\
\text { GOD }\end{array}$ & [86] \\
\hline TFT & $\begin{array}{l}\mathrm{H}_{2} \mathrm{O}_{2} \& \\
\text { Glucose }\end{array}$ & $\begin{array}{c}\text { PEDOT- } \\
\mathrm{TiO}_{2} \text {-GOD }\end{array}$ & 1 & $0.126 \%$ /decade & $0.001-5$ & $\begin{array}{c}\mathrm{V}_{\mathrm{ds}}:-0.1 \mathrm{~V} \\
\mathrm{~V}_{\mathrm{g}}: 0.4 \mathrm{~V}\end{array}$ & $\begin{array}{c}\sim 1000 \mathrm{~s} \\
\text { (est.) }\end{array}$ & $\begin{array}{l}\text { Buffer: PBS } \\
(10 \mathrm{mM}) \\
\text { Working } \\
\text { pH: } 7.0\end{array}$ & $\begin{array}{l}\text { Stable for } \\
\text { 10 days with } \\
\text { intermittent } \\
\text { testing }\end{array}$ & [85] \\
\hline $\begin{array}{c}\text { Liquid gate } \\
\text { FET }\end{array}$ & $\mathrm{H}_{2} \mathrm{O}_{2}$ & $\begin{array}{l}\text { rGO-PPy } \\
\text { NTs }\end{array}$ & $0.1 \mathrm{nM}$ & $2 \% /$ decade & $0.1-100 \mathrm{nM}$ & $\begin{array}{c}\mathrm{V}_{\mathrm{g}}: 0.1 \mathrm{~V} \\
\mathrm{~V}_{\mathrm{ds}}:-0.01 \\
\mathrm{~V}\end{array}$ & $<1 \mathrm{~s}$ & $\begin{array}{l}\text { Buffer: PBS } \\
\text { Working } \\
\text { pH: } 7.4\end{array}$ & $\begin{array}{l}\text { Stable up to } \\
1 \text { month, when } \\
\text { stored in air }\end{array}$ & $\begin{array}{l}{[66,} \\
67]\end{array}$ \\
\hline \multicolumn{11}{|c|}{ Metal oxides } \\
\hline $\begin{array}{l}\text { Glass-ITO- } \\
\mathrm{SnO}_{2}\end{array}$ & Glucose & $\begin{array}{l}\text { GOD- } \\
\mathrm{MnO}_{2}\end{array}$ & 2700 & $\begin{array}{c}2.35 \\
\mathrm{mV} / \mathrm{mM}\end{array}$ & $<20$ & No bias & 720 & $\begin{array}{c}\text { Buffer: } \\
\text { Phosphate- } \\
\text { KOH (5 mM) } \\
\text { Working pH: } \\
\quad 8.1\end{array}$ & $\begin{array}{l}\text { Dynamic range } \\
\text { strongly } \\
\text { depends on } \mathrm{pH} \\
\text { value }\end{array}$ & [68] \\
\hline $\mathrm{Si}_{3} \mathrm{~N}_{4}$-FET & Glucose & $\begin{array}{c}\mathrm{GOD}- \\
\mathrm{MnO}_{2} \\
\mathrm{NPs}\end{array}$ & 20 & NR & $0.025-1.9$ & No bias & $\sim 140 \mathrm{~s}$ & $\begin{array}{l}\text { Buffer: Tris (10 } \\
\text { mM) } \\
\text { Working pH: } \\
7.4\end{array}$ & $\begin{array}{l}\text { Repeatability: } \\
1.9 \% \text { (RSD) for } 7 \\
\text { measurements }\end{array}$ & [62] \\
\hline \multirow{3}{*}{ FET } & \multirow{3}{*}{$\mathrm{H}_{2} \mathrm{O}_{2}$} & $\begin{array}{l}\text { Iridium } \\
\text { oxide }\end{array}$ & 100 & $\begin{array}{c}400 \\
\mathrm{mV} / \mathrm{dec}\end{array}$ & $0.1-10$ & $\mathrm{I}_{\text {bias }}: 25 \mathrm{nA}$ & \multirow{3}{*}{ NR } & $\begin{array}{l}\text { Working } \mathrm{pH}: \\
3.5-9\end{array}$ & \multirow{3}{*}{-} & \multirow{3}{*}{ [69] } \\
\hline & & $\begin{array}{l}\text { Prussian } \\
\text { blue }\end{array}$ & 10 & $\begin{array}{c}290 \\
\mathrm{mV} / \mathrm{dec}\end{array}$ & $0.01-1$ & $\mathrm{I}_{\text {bias }}: 50 \mathrm{nA}$ & & $\begin{array}{l}\text { Working } \mathrm{pH} \text { : } \\
4.5-6\end{array}$ & & \\
\hline & & $\begin{array}{l}\text { Os-PVP- } \\
\text { HRP }\end{array}$ & 0.1 & $\begin{array}{c}700 \\
\mathrm{mV} / \mathrm{dec}\end{array}$ & $10^{-7}-10^{-5} \mathrm{M}$ & $\mathrm{I}_{\text {bias }}: 25 \mathrm{nA}$ & & $\begin{array}{l}\text { Working pH: } \\
4.5-6\end{array}$ & & \\
\hline $\mathrm{Ta}_{2} \mathrm{O}_{5}$-FET-Pt & $\mathrm{H}_{2} \mathrm{O}_{2}$ & $\begin{array}{l}\text { Perovskite } \\
\text { oxide }\end{array}$ & 4 & $35 \mathrm{mV} / \mathrm{dec}$ & $0.005-0.2$ & $\mathrm{I}_{\text {bias }}: 25 \mathrm{nA}$ & 1800 & $\begin{array}{c}\text { Buffer: } \\
\text { Phosphate } \\
\text { Working pH: } 7\end{array}$ & $\begin{array}{l}\text { Change in } \\
\text { stoichiometry } \\
\text { of oxide can } \\
\text { result in lower } \\
\text { detection limit }\end{array}$ & [44] \\
\hline FET & $\mathrm{H}_{2} \mathrm{O}_{2}$ & $\mathrm{TiO}_{2}$ & NR & $\begin{array}{c}4.5 \\
\mathrm{mV} / \mu \mathrm{M} \\
(\mathrm{DMEM} \\
\text { media) }\end{array}$ & NR & $\begin{array}{l}\mathrm{I}_{\mathrm{ds}}: 0.1 \mathrm{~mA} \\
\mathrm{~V}_{\mathrm{ds}}: 1 \mathrm{~V}\end{array}$ & 300 (est.) & $\begin{array}{l}\text { Buffer: } \\
\text { Phosphate }\end{array}$ & DMEM media & [71] \\
\hline FET & Glucose & $\begin{array}{l}\mathrm{ZnO}-\mathrm{NiO} \\
\text { quantum } \\
\text { dots }\end{array}$ & 26 & $\begin{array}{c}13.14 \mu \mathrm{A} \\
\mathrm{mM}^{-1}(0.001- \\
10 \\
\mathrm{mM})\end{array}$ & $0.001-50$ & $\begin{array}{l}\mathrm{V}_{\mathrm{g}}: 1.2-2 \mathrm{~V} \\
\mathrm{~V}_{\mathrm{ds}}: 0.0 \mathrm{~V}\end{array}$ & NR & $\begin{array}{l}\text { Buffer: PBS (10 } \\
\text { mM) } \\
\text { Working pH: } \\
7.4\end{array}$ & $\begin{array}{l}\text { Tested in whole } \\
\text { blood and } \\
\text { serum }\end{array}$ & [94] \\
\hline \multirow[t]{2}{*}{$\begin{array}{c}\text { Liquid gate } \\
\text { FET }\end{array}$} & Glucose & $\begin{array}{c}\mathrm{ZnO} \\
\text { rod-GOD }\end{array}$ & 0.07 & $\begin{array}{c}32.27 \mu \mathrm{A} \\
\mathrm{mM}^{-1} \mathrm{~cm}^{-2}\end{array}$ & $0.05-70$ & $\mathrm{~V}_{\mathrm{g}}: 0-2 \mathrm{~V}$ & NR & \multirow{2}{*}{$\begin{array}{l}\text { Buffer: PBS } \\
\text { (50 mM) } \\
\text { Working } \\
\text { pH: } 7.4\end{array}$} & \multirow[t]{2}{*}{$\begin{array}{l}\text { Mice blood, } \\
\text { serum }\end{array}$} & \multirow[t]{2}{*}[74]{} \\
\hline & Cholesterol & $\begin{array}{c}\mathrm{ZnO} \\
\text { rod-COD }\end{array}$ & 0.04 & $\begin{array}{c}17.1 \mu \mathrm{A} \\
\mathrm{mM}^{-1} \mathrm{~cm}^{-2}\end{array}$ & $0.01-45$ & $V_{g}: 2-3 V$ & NR & & & \\
\hline \multicolumn{11}{|c|}{ Carbon nanomaterials } \\
\hline $\begin{array}{l}\text { Graphene- } \\
\text { FET }\end{array}$ & Glucose & GOD & 100 & $\begin{array}{c}\sim 1 \\
\mu \mathrm{A} / \mathrm{mM} \\
\text { (est.) }\end{array}$ & $<10$ & $\begin{array}{c}\mathrm{V}_{\mathrm{ds}}: 0.1 \mathrm{~V} \\
\mathrm{~V}_{\mathrm{g}}: 0 \mathrm{~V}\end{array}$ & $\begin{array}{l}<200 \mathrm{~s} \\
\text { (est.) }\end{array}$ & $\begin{array}{c}\text { Buffer: PBS } \\
\text { (10 mM) } \\
\text { Working } \\
\text { pH: } 7.2\end{array}$ & $\begin{array}{l}\text { Glutamate was } \\
\text { also detected } \\
\text { using the sensor } \\
\text { with GluD }\end{array}$ & [77] \\
\hline OTFT & Glucose & $\begin{array}{l}\text { Graphene- } \\
\text { Chitosan- } \\
\text { GOD }\end{array}$ & 0.01 & $\begin{array}{c}370 \\
\mathrm{mV} / \mathrm{dec}\end{array}$ & $0.01-1 \mu \mathrm{M}$ & $\begin{array}{c}\mathrm{V}_{\mathrm{g}}: 0.4 \mathrm{~V} \\
\mathrm{~V}_{\mathrm{ds}}: 0.05 \mathrm{~V}\end{array}$ & $\sim 500 \mathrm{~s}$ & $\begin{array}{l}\text { Buffer: PBS } \\
\text { Working } \\
\text { pH: } 7.4\end{array}$ & $\begin{array}{l}\text { Investigated the } \\
\text { effect of } \\
\text { interference of } \\
\text { UA and AA }\end{array}$ & [98] \\
\hline
\end{tabular}


Table 3. Cont.

\begin{tabular}{|c|c|c|c|c|c|c|c|c|c|c|}
\hline Substrate & $\begin{array}{c}\text { Target } \\
\text { Analyte }\end{array}$ & $\begin{array}{l}\text { Ligand/ } \\
\text { Enzyme }\end{array}$ & $\begin{array}{l}\text { LOD } \\
(\mu \mathrm{M})\end{array}$ & Sensitivity & $\begin{array}{c}\text { Measuring } \\
\text { Range (mM) }\end{array}$ & OC & $\begin{array}{l}\text { Response } \\
\text { Time (s) }\end{array}$ & $\begin{array}{c}\text { Working pH \& } \\
\text { Buffer }\end{array}$ & Comments & Ref \\
\hline $\begin{array}{l}\text { Graphene- } \\
\text { FET }\end{array}$ & Glucose & $\begin{array}{l}\text { Silk fibroin- } \\
\text { GOD }\end{array}$ & 100 & $\begin{array}{c}2.5 \\
\mu \mathrm{A} / \mathrm{mM}\end{array}$ & $0.1-10$ & $\begin{array}{c}\mathrm{V}_{\mathrm{g}}: 0 \mathrm{~V} \\
\mathrm{~V}_{\mathrm{ds}}: 0.1 \mathrm{~V}\end{array}$ & $\sim 100 \mathrm{~s}$ & $\begin{array}{c}\text { Buffer: PBS } \\
\text { (10 mM) } \\
\text { Working } \\
\text { pH: } 7.4\end{array}$ & $\begin{array}{c}\text { Stable for } \\
10 \text { months at } \\
\text { room } \\
\text { temperature }\end{array}$ & [79] \\
\hline FET & $\begin{array}{l}\mathrm{H}_{2} \mathrm{O}_{2} \& \\
\text { Glucose }\end{array}$ & $\begin{array}{l}\text { Graphene- } \\
\text { Chitosan- } \\
\text { PtNPs- } \\
\text { GOD }\end{array}$ & 0.03 & $\begin{array}{c}91.7 \\
\mathrm{mV} / \mathrm{dec}\end{array}$ & $30 \mathrm{nM}-1 \mathrm{mM}$ & $\begin{array}{c}\mathrm{V}_{\mathrm{g}}: 0.7 \mathrm{~V} \\
\mathrm{~V}_{\mathrm{ds}}: 0.05 \mathrm{~V}\end{array}$ & $\begin{array}{c}\sim 100 \mathrm{~s} \\
\text { (est.) }\end{array}$ & $\begin{array}{c}\text { Buffer: PBS } \\
\text { Working } \\
\text { pH: } 7.2\end{array}$ & $\begin{array}{c}\text { No interference } \\
\text { was observed } \\
\text { from AA and } \\
\text { UA }\end{array}$ & [99] \\
\hline rGO-FET & $\mathrm{H}_{2} \mathrm{O}_{2}$ & $\mathrm{MoS}_{2}$ & $1 \mathrm{pM}$ & $0.46 \% / \mathrm{dec}$ & $1 \mathrm{pM}-100 \mathrm{nM}$ & $\begin{array}{c}\mathrm{V}_{\mathrm{g}}: 0.1 \mathrm{~V} \\
\mathrm{~V}_{\mathrm{ds}}: 0.01 \mathrm{~V}\end{array}$ & $\sim 1 \mathrm{~s}$ & $\begin{array}{c}\text { Buffer: PBS } \\
\text { Working } \\
\text { pH: } 7.4\end{array}$ & HeLa Cells & [25] \\
\hline FET & $\mathrm{H}_{2} \mathrm{O}_{2}$ & $\begin{array}{l}\text { Graphene- } \\
\text { Cyt-c }\end{array}$ & $0.1 \mathrm{pM}$ & $14 \% / \mathrm{dec}$ & $0.1-100 \mathrm{pM}$ & $\begin{array}{c}\mathrm{V}_{\mathrm{g}}: 1.75 \mathrm{~V} \\
\mathrm{~V}_{\mathrm{ds}}: 0.001 \mathrm{~V}\end{array}$ & $<1 \mathrm{~s}$ & $\begin{array}{c}\text { Buffer: PBS } \\
\text { Working } \\
\text { pH: } 7.4\end{array}$ & $\begin{array}{c}\text { No interference } \\
\text { from UA, AA, } \\
\text { dopamine, and } \\
\text { glutamate }\end{array}$ & [24] \\
\hline \multicolumn{11}{|c|}{ Others } \\
\hline $\mathrm{SiO}_{2}-\mathrm{MOSC}$ & Glucose & HRP-GOD & 5000 & $\begin{array}{c}1.76 \\
\mathrm{nA} / \mathrm{cm}^{2} \mathrm{M}\end{array}$ & $<2 \mathrm{M}$ & $\mathrm{V}_{\mathrm{g}}: 5 \mathrm{~V}$ & 1200 & $\begin{array}{l}\text { Dry sensor so } \\
\text { no need for a } \\
\text { buffer solution }\end{array}$ & - & [70] \\
\hline $\begin{array}{l}\text { Polysilicon } \\
\text { wire-ISFET }\end{array}$ & $\begin{array}{l}\mathrm{H}_{2} \mathrm{O}_{2} \& \\
\text { Glucose }\end{array}$ & $\begin{array}{l}\text { APTES- } \\
\text { SiNPs-UV } \\
\text { treatment }\end{array}$ & $32 \mathrm{pM}$ & $\begin{array}{c}12 \\
\mathrm{AmM}^{-1} \mathrm{~cm}^{-2}\end{array}$ & $10^{-10}-10^{-3} \mathrm{M}$ & $\mathrm{V}_{\mathrm{ds}}: 5 \mathrm{~V}$ & NR & $\begin{array}{l}\text { Tested solution } \\
\text { volume: } 0.03 \mathrm{pL} \\
\text { (Dry sensor) }\end{array}$ & Serum & [73] \\
\hline
\end{tabular}

The sensor exhibited a good response to glucose concentrations from 0.1 to $10 \mathrm{mM}$ with a detection limit of $0.1 \mathrm{mM}$. The response time was estimated to be $\sim 200-500 \mathrm{~s}$ and the sensitivity of the sensors was $\sim 1.5 \mu \mathrm{A} / \mathrm{mM}$ from $0.1 \mathrm{mM}$ to $2 \mathrm{mM}$ of glucose concentrations. A similar graphene based sensor was also reported [78]. The measuring range of the sensor was 3.3-10.9 mM with a detection limit of $3.3 \mathrm{mM}$. The response time of the sensor was $\sim 60 \mathrm{~s}$ which was faster than the previously reported FET [77]. Graphene based FETs can work both in the p-doped $\left(\mathrm{V}_{\mathrm{g}}<\right.$ Dirac point) or $\mathrm{n}$-doped $\left(\mathrm{V}_{\mathrm{g}}>\right.$ Dirac point) regime, depending on the applied gate potential.

Another study demonstrated the use of graphene flakes along with chitosan to improve the sensitivity of a TFT with a platinum gate electrode [98]. The sensitivity was improved from $41 \mathrm{mV}$ /decade (no graphene) to $370 \mathrm{mV} /$ decade with graphene along with a two-order of magnitude improvement in the detection limit from $1000 \mathrm{nM}$ to $10 \mathrm{nM}$. The improvement in the sensitivity of the device was a result of high conductivity of the graphene and the larger surface to volume ratio of the composite film. The measuring range of the sensor was from $10 \mathrm{nM}$ to $1 \mu \mathrm{M}$ and the response time of the sensor was $\sim 500 \mathrm{~s}$. The same group has demonstrated an improvement of the electrocatalytic activity of the graphene film by depositing platinum nanoparticles on the film [99]. The detection limit was enhanced from $10 \mu \mathrm{M}$ (without PtNPs) to $0.03 \mu \mathrm{M}$ (with Pt NPs) of $\mathrm{H}_{2} \mathrm{O}_{2}$ concentration. The sensitivity of the sensor was $91.7 \mathrm{mV} /$ decade when the $\mathrm{H}_{2} \mathrm{O}_{2}$ concentration lies between 3-300 $\mu \mathrm{M}$. The response time of the sensor was $\sim 200 \mathrm{~s}$. The same group combined graphene sheets with cytochrome $\mathrm{c}$ to further extend the detection limit of the FET sensor to the femtomolar range and a rapid response time of $<1 \mathrm{~s}$ [24] (Figure 7e,f). The ultralow sensitivity (100 fM) of the sensor can be attributed to the high charge carrier mobility, large surface area and high conductivity of single layer graphene sheet. In addition, cytochrome c imparts the required specificity to the sensors for such low concentration measurements. The measuring range of the sensor was $100 \mathrm{fM}$ to $100 \mathrm{pM}$ with a sensitivity of $16 \%$ current change per decade of concentration change.

Another ultrasensitive $\mathrm{H}_{2} \mathrm{O}_{2}$ FET sensor was fabricated using r-GO with $\mathrm{MoS}_{2}$, another $2 \mathrm{D}$ material [25]. $\mathrm{MoS}_{2}$ acts as a catalytic layer to catalyze the conversion of $\mathrm{H}_{2} \mathrm{O}_{2}$ and imparts the required sensitivity for selective $\mathrm{H}_{2} \mathrm{O}_{2}$ detection. The measuring range of the sensor was $1 \mathrm{pM}$ to $100 \mathrm{nM}$ with a sensitivity of $0.46 \%$ current change per decade change in $\mathrm{H}_{2} \mathrm{O}_{2}$ concentration which was far lesser than the graphene based sensor reported by Lee et al. [24]. The response time was around $100 \mathrm{~s}$. 
Carbon based nanomaterials offer promising properties for ultra-sensitive $\mathrm{H}_{2} \mathrm{O}_{2}$ FET sensors. The sensing surfaces exhibit several advantages such as excellent selectivity, simple immobilization processes for enzyme attachment, and low-cost materials. The surfaces fabricated using graphene have superior properties which can be attributed to effective and uniform enzyme functionalization due to the flat surface of graphene, a functionalization that could change the number of tube-to-tube contacts for CNTs, and reduced sensitivity of CNT films due to the presence of metallic CNTs [77].

\section{Outlook}

An ideal sensor should have high accuracy, selectivity, specificity, reproducibility, and environmental stability. To address selectivity and specificity, both enzymatic and nonenzymatic methods are used to develop $\mathrm{H}_{2} \mathrm{O}_{2}$ sensors. Enzymatic sensors use peroxidase enzymes to measure the $\mathrm{H}_{2} \mathrm{O}_{2}$ concentration and exhibit excellent selectivity along with good sensitivity due to high affinity for the analyte. However, these sensors require extra fabrication steps for efficient enzyme immobilization on the substrate without affecting the enzyme activity. Multiple immobilization processes are used to preserve the activity of the enzyme while immobilizing it on the electrode. However, in most immobilization processes a significant reduction in enzymatic activity is observed. Further, the activity of the enzymes is also affected by the environmental conditions which limit the use of enzymatic sensors under specific conditions and defined shelf life. Limited studies have attempted to improve the enzyme stability. One such study used silk fibroin as the immobilizing matrix to improve the enzyme stability [79]. More studies are required to improve the long-term stability of the enzyme under various environmental conditions.

Considerable effort has been made to develop non-enzymatic sensors and artificial enzymes. Non-enzymatic sensors utilize numerous compounds with peroxidase-like activity such as Prussian blue, nanomaterials, metal oxide particles like $\mathrm{MnO}_{2}, \mathrm{SnO}_{2}, \mathrm{TiO}_{2}, \mathrm{ZnO}$ etc., perovskite oxides, and others. Unlike natural enzymes, catalysts are stable in environmental conditions and less expensive. These catalysts can be more robust and tailored according to the required fabrication process and applications. Future developments in this field will focus on overcoming the limitations of existing sensors and extending their application to new areas. Some of these developments have been identified and discussed below.

\subsection{Contact Resistance and Its Engineering}

Contacts are the connection between the material like graphene, CNT, etc. and the electronics output. The contact resistance between the 2D materials and metal limits the scalability and the device performance due to the presence of a Schottky barrier. Unfortunately, less work has been done to reduce the contact resistance for these FETs. One of the techniques used to reduce the contact resistance is to change the contact metal to a lower work function metal. For instance, using scandium with $\mathrm{MoS}_{2}$ reduced the Schottky barrier height to $30 \mathrm{meV}$ and the contact resistance of the FET to $0.65 \mathrm{k} \Omega / \mu \mathrm{m}[105,106]$. Another strategy used to reduce the contact resistance is by using a metal which can interact strongly with the 2D material layer. Mo metal contacts with $\mathrm{MoS}_{2}$ reduced the contact resistance. However, this method is not suitable for all metals or 2D material layers [106]. Further work needs to be done to improve the scalability and reproducibility of the contact electrodes especially when flexible sensors are manufactured.

\subsection{Real Sample Testing}

Most of the reported sensors have demonstrated good sensor selectivity and specificity for $\mathrm{H}_{2} \mathrm{O}_{2}$ measurements in defined sample matrices like buffers. However, these sensors could face challenges when tested in real sample matrices like blood, sweat, urine, cell media etc., due to the presence of other interfering analytes present and through non-specific adsorption. Therefore, selectivity becomes a more important parameter than other sensor parameters such as response time, sensitivity etc., due to this complex envi- 
ronment. Further, the sensor should exhibit the required LOD and sensitivity under the given environmental conditions. The desirable sensor properties also vary depending on the final applications. For instance, cell viability measurements require the detection of $\mathrm{H}_{2} \mathrm{O}_{2}$ at sub-micromolar concentrations while $\mathrm{H}_{2} \mathrm{O}_{2}$-based lactate sensors work within the millimolar range.

Chemiresistive $\mathrm{H}_{2} \mathrm{O}_{2}$ sensors work mostly within a millimolar concentration change with one exception which worked till nanomolar. These sensors also have a response time within a range of 3-400 s which makes them a good low-cost alternative for $\mathrm{H}_{2} \mathrm{O}_{2}$ measurements in multiple areas. 3 out of 7 studies reported here have performed interference testing $[19,20,49]$. One of the device was exposed to common interfering molecules present in blood such as ascorbic acid, uric acid, acetoaminophen [49]. Other device was tested against common sugars like sucrose and fructose [19]. Third device was exposed to ethanol, methanol and acetone to investigate the interference from these molecules. Therefore, there is a need to do exhaustive interference testing with common interferents present in the different samples like blood, urine, and environmental samples. Only one sensor was tested with a real sample like juice, and iced tea [19]. For commercial success, the sensors should be tested in real samples. Moreover, chemiresistive sensors suffer from nonspecific adsorption which can be prevented either by sample preparation or coating the sensor surface to increase the selectivity of the sensors.

Conductometric sensors have a more diverse measuring range where a few sensors have measuring ranges similar to the chemiresistive sensors (millimolar range) while others can measure $\mathrm{H}_{2} \mathrm{O}_{2}$ concentrations as low as $0.01 \mathrm{ng} / \mathrm{mL}$. However, the sensors had longer response times (5-30 $\mathrm{min}$ ). These sensors were used to measure $\mathrm{H}_{2} \mathrm{O}_{2}$ in relatively wider ranges for applications including food manufacturing and processing, beverages, and immunoassays. Four out of eight studies reported were tested in real samples like human serum [21,58], alcoholic beverages [55], and yogurt [57]. The sensor response is strongly affected by the ionic strength of the sample. Therefore, these sensors need sample dilutions or a preparation step for the measurement. Recent studies are working towards coatings which can reduce the effect of buffer strength on the sensor response.

FETs have the lowest reported LOD of $0.1 \mathrm{pM}$ and a broad range of response times ranging from $<1 \mathrm{~s}$ to $30 \mathrm{~min}$ for $\mathrm{H}_{2} \mathrm{O}_{2}$ measurements. This sensor group was tested with a wider range of samples including blood, serum, live cell cultures etc. These sensors also have broad measuring range where a few sensors worked in the millimolar range and others worked down to picomolar concentrations. Recent studies showed no significant effect of interfering species like ascorbic acid, uric acid, dopamine and glutamate. FET based sensors can be good candidates for real time $\mathrm{H}_{2} \mathrm{O}_{2}$ monitoring. Therefore, studies should focus more on testing the sensors in real samples and the long-term effect of the sample matrices on the sensor performance.

\subsection{In Vivo Applications}

In vivo $\mathrm{H}_{2} \mathrm{O}_{2}$ monitoring is useful for applications such as medical diagnostics, food processing industries etc. At present, none of the solid-state sensors are used for in vivo monitoring. Key factors crucial to consider while designing an in vivo sensor for reliable measurements are selectivity, and compatibility with the biological matrix. Selectivity is the most important parameter for sensors to generate accurate results. Unlike in vitro conditions, in vivo applications pose challenges due to the presence of coexisting compounds and dynamic environmental conditions. For example, in vivo detection of $\mathrm{H}_{2} \mathrm{O}_{2}$ in the human body can be affected by the presence of generated metabolites such as ascorbic acid, uric acid and others. To attain selectivity under such conditions, the reaction kinetics must be modified to ensure that the target analyte reaction is the favorable reaction. Selectivity can also be attained by using highly selective active molecules like enzymes or enzyme mimics for detection. The enzyme FET sensor is a good candidate for continuous $\mathrm{H}_{2} \mathrm{O}_{2}$ monitoring because FETs can be mass manufactured and miniaturized to accommodate multiple sensors on a same chip. However, FETs are currently affected by high drift rates 
and poor electrical insulation for the electrical contacts. The sensors can be modified using selective membranes to reduce the interference from coexisting compounds. A second factor that needs to be considered is compatibility of the sensor in the matrix. For instance, a sensor can give unpredictable results if its surface is fouled when placed in the sample matrix. The compatibility of the sensor is generally improved by reducing size which reduces the sensor exposure to the sample, but this can also impact the sensor sensitivity. To improve sensitivity, the sensing surface is often coated with antifouling materials that may be composed of nanomaterials such as metal nanoparticles. Sensor fouling can affect the sensor response both in terms of specificity and sensitivity. Researchers are exploring various physical and chemical methods to prevent fouling of the electrode surface. Physical methods such as membrane filtration, surface topographical engineering and chemical surface modifiers like polyethylene glycol are commonly used as anti-fouling strategies. A recent review has summarized various methods to prevent fouling in both in vitro and in vivo conditions [107]. Addressing the long term fouling issue will be critical in the effective demonstration of in-vivo application of these sensors.

\section{Conclusions and Future Directions}

The review has analyzed the performance of three types of solid state $\mathrm{H}_{2} \mathrm{O}_{2}$ sensors: chemiresistive, conductometric and FET. These sensors showed a good potential for lowcost, and easy to manufacture $\mathrm{H}_{2} \mathrm{O}_{2}$ measurement systems. Further, a wide range of new materials, including metal nanoparticles, carbon nanomaterials, and other materials, are also used to increase the sensitivity of these solid-state sensors and to reduce the potential applied for the measurements. Recent studies have also investigated the effect of common interferents on the sensor's response. However, there is still a need to conduct more exhaustive studies to test these sensors in real samples and subsequently for in vivo monitoring of $\mathrm{H}_{2} \mathrm{O}_{2}$.

$\mathrm{H}_{2} \mathrm{O}_{2}$ is an important molecule in various industrial applications like textile, pharmaceuticals, food processing, cleaning and disinfection. Solid state sensors can work in a wide range of detection as summarized. However, these sensors still need improvement in sensitivity and selectivity for $\mathrm{H}_{2} \mathrm{O}_{2}$ in various sample matrix to become widely applicable in industrial applications mentioned above. Nanomaterials like graphene, CNT, and graphene oxide are used to improve the sensor performance in environmental conditions. More efforts will be needed to tackle the sensor fouling issues in different sample matrix to enable continuous monitoring required for industrial applications. Recent studies are working to reduce the limit of detection using FET based sensors.

In summary, solid state sensors could potentially be used for different applications due to simple fabrication process, wider range of detection and low-cost. Chemiresistive and conductometric sensors can be good alternatives to electrochemical sensors as they do not require reference electrodes which poses a challenge for miniaturization of amperometric and potentiometric electrochemical sensors.

Author Contributions: Conceptualization, V.P., P.R.S.; literature survey and data collection; V.P.; literature analysis: V.P.; writing—original draft preparation, V.P.; writing—review and editing, V.P.; P.K.; P.R.S.; supervision and project administration, P.R.S. All authors have read and agreed to the published version of the manuscript.

Funding: The authors acknowledge support from the Global Waters Futures program and the Natural Sciences and Engineering Research Council of Canada. PRS acknowledges support from the Canada Research Chairs Program.

Institutional Review Board Statement: Not Applicable.

Informed Consent Statement: Not applicable.

Data Availability Statement: Data is contained within the article or supplementary material.

Conflicts of Interest: The authors declare no conflict of interest. 


\section{References}

1. Chen, S.; Yuan, R.; Chai, Y.; Hu, F. Electrochemical sensing of hydrogen peroxide using metal nanoparticles: A review. Microchim. Acta 2013, 180, 15-32. [CrossRef]

2. Giorgio, M.; Trinei, M.; Migliaccio, E.; Pelicci, P.G. Hydrogen peroxide: A metabolic by-product or a common mediator of ageing signals? Nat. Rev. Mol. Cell Biol. 2007, 8, 722-728. [CrossRef] [PubMed]

3. Miller, E.W.; Dickinson, B.C.; Chang, C.J. Aquaporin-3 mediates hydrogen peroxide uptake to regulate downstream intracellular signaling. Proc. Natl. Acad. Sci. USA 2010, 107, 15681-15686. [CrossRef] [PubMed]

4. Sies, H. Hydrogen peroxide as a central redox signaling molecule in physiological oxidative stress: Oxidative eustress. Redox Biol. 2017, 11, 613-619. [CrossRef] [PubMed]

5. Pi, J.; Bai, Y.; Zhang, Q.; Wong, V.; Floering, L.M.; Daniel, K.; Reece, J.M.; Deeney, J.T.; Andersen, M.E.; Corkey, B.E.; et al. Reactive Oxygen Species as a Signal in Glucose-Stimulated Insulin Secretion. Diabetes 2007, 56, 1783-1791. [CrossRef]

6. Liou, G.Y.; Storz, P. Reactive oxygen species in cancer. Free Radic. Res. 2010, 44, 479-496. [CrossRef]

7. Barnham, K.J.; Masters, C.L.; Bush, A.I. Neurodegenerative diseases and oxidatives stress. Nat. Rev. Drug Discov. 2004, 3, 205-214. [CrossRef]

8. Rao, A.V.; Balachandran, B. Role of Oxidative Stress and Antioxidants in Neurodegenerative Diseases. Nutr. Neurosci. 2002, 5, 291-309. [CrossRef]

9. Schöning, M.J.; Poghossian, A. Recent advances in biologically sensitive field-effect transistors (BioFETs). Analyst 2002, 127, 1137-1151. [CrossRef]

10. Andersen, B.M.; Rasch, M.; Hochlin, K.; Jensen, F.H.; Wismar, P.; Fredriksen, J.E. Decontamination of rooms, medical equipment and ambulances using an aerosol of hydrogen peroxide disinfectant. J. Hosp. Infect. 2006, 62, 149-155. [CrossRef]

11. Burmistrova, N.A.; Kolontaeva, O.A.; Duerkop, A. New Nanomaterials and Luminescent Optical Sensors for Detection of Hydrogen Peroxide. Chemosensors 2015, 3, 253-273. [CrossRef]

12. Guo, H.; Aleyasin, H.; Dickinson, B.C.; Haskew-Layton, R.E.; Ratan, R.R. Recent advances in hydrogen peroxide imaging for biological applications. Cell Biosci. 2014, 4, 1-10. [CrossRef] [PubMed]

13. Chen, W.; Cai, S.; Ren, Q.Q.; Wen, W.; Zhao, Y.D. Recent advances in electrochemical sensing for hydrogen peroxide: A review. Analyst 2012, 137, 49-58. [CrossRef] [PubMed]

14. Liu, H.; Weng, L.; Yang, C. A review on nanomaterial-based electrochemical sensors for H2O2, H2S and NO inside cells or released by cells. Microchim. Acta 2017, 184, 1267-1283. [CrossRef]

15. Shamkhalichenar, H.; Choi, J.-W. Review-Non-Enzymatic Hydrogen Peroxide Electrochemical Sensors Based on Reduced Graphene Oxide. J. Electrochem. Soc. 2020, 167, 037531. [CrossRef]

16. Aziz, A.; Asif, M.; Ashraf, G.; Azeem, M.; Majeed, I.; Ajmal, M.; Wang, J.; Liu, H. Advancements in electrochemical sensing of hydrogen peroxide, glucose and dopamine by using 2D nanoarchitectures of layered double hydroxides or metal dichalcogenides. A review. Microchim. Acta 2019, 186, 671. [CrossRef]

17. Chen, L.; Compton, R.G. Reference Electrodes for Electrochemical Sensors Based on Redox Couples Immobilized within Nafion Films. ACS Sens. 2019, 4, 1716-1723. [CrossRef]

18. Aydoğdu, G.; Zeybek, D.K.; Pekyardımcı, S..; Kilic, E. A novel amperometric biosensor based on ZnO nanoparticles-modified carbon paste electrode for determination of glucose in human serum. Artif. Cells Nanomed. Biotechnol. 2013, 41, 332-338. [CrossRef]

19. Soylemez, S.; Yoon, B.; Toppare, L.; Swager, T.M. Quaternized Polymer-Single-Walled Carbon Nanotube Scaffolds for a Chemiresistive Glucose Sensor. ACS Sens. 2017, 2, 1123-1127. [CrossRef]

20. Song, E.; Choi, J.W. A selective hydrogen peroxide sensor based on chemiresistive polyaniline nanowires modified with silver catalytic nanoparticles. J. Micromech. Microeng. 2014, 24, 24. [CrossRef]

21. Li, L.; Guo, W.; Lin, Y.; Tang, D.; Liu, J. Facile and feasible conductometric immunoanalytical assay for alpha-fetoprotein using platinum-functionalized graphitic carbon nitride nanosheets. Anal. Methods 2018, 10, 4886-4893. [CrossRef]

22. Valencia, G.A.; De Oliveira Vercik, L.C.; Vercik, A. A new conductometric biosensor based on horseradish peroxidase immobilized on chitosan and chitosan/gold nanoparticle films. J. Polym. Eng. 2014, 34, 633-638. [CrossRef]

23. Nouira, W.; Maaref, A.; Elaissari, H.; Vocanson, F.; Siadat, M.; Jaffrezic-Renault, N. Comparative study of conductometric glucose biosensor based on gold and on magnetic nanoparticles. Mater. Sci. Eng. C 2013, 33, 298-303. [CrossRef]

24. Lee, S.H.; Kim, K.H.; Seo, S.E.; Kim, M.I.; Park, S.J.; Kwon, O.S. Cytochrome C-decorated graphene field-effect transistor for highly sensitive hydrogen peroxide detection. J. Ind. Eng. Chem. 2020, 83, 29-34. [CrossRef]

25. Zheng, C.; Jin, X.; Li, Y.; Mei, J.; Sun, Y.; Xiao, M.; Zhang, H.; Zhang, Z.; Zhang, G.J. Sensitive Molybdenum Disulfide Based Field Effect Transistor Sensor for Real-time Monitoring of Hydrogen Peroxide. Sci. Rep. 2019, 9, 1-9. [CrossRef]

26. Shan, J.; Li, J.; Chu, X.; Xu, M.; Jin, F.; Wang, X.; Ma, L.; Fang, X.; Wei, Z.; Wang, X. High sensitivity glucose detection at extremely low concentrations using a MoS2-based field-effect transistor. RSC Adv. 2018, 8, 7942-7948. [CrossRef]

27. Sugiyasu, K.; Swager, T.M. Conducting-Polymer-Based Chemical Sensors: Transduction Mechanisms. Bull. Chem. Soc. Jpn. 2007, 80, 2074-2083. [CrossRef]

28. Pundir, C.S.; Deswal, R.; Narwal, V. Quantitative analysis of hydrogen peroxide with special emphasis on biosensors. Bioprocess Biosyst. Eng. 2018, 41, 313-329. [CrossRef]

29. Zhang, R.; Chen, W. Recent advances in graphene-based nanomaterials for fabricating electrochemical hydrogen peroxide sensors. Biosens. Bioelectron. 2017, 89, 249-268. [CrossRef] 
30. Olenin, A.Y. Methods of nonenzymatic determination of hydrogen peroxide and related reactive oxygen species. J. Anal. Chem. 2017, 72, 243-255. [CrossRef]

31. Thatikayala, D.; Ponnamma, D.; Sadasivuni, K.K.; Cabibihan, J.J.; Al-Ali, A.K.; Malik, R.A.; Min, B. Progress of Advanced Nanomaterials in the Non-Enzymatic Electrochemical Sensing of Glucose and $\mathrm{H}_{2} \mathrm{O}_{2}$. Biosensors 2020, 10, 151. [CrossRef] [PubMed]

32. Koo, W.-T.; Jang, J.-S.; Kim, I.-D. Metal-Organic Frameworks for Chemiresistive Sensors. Chem 2019, 5, 1938-1963. [CrossRef]

33. Kruse, P. Review on water quality sensors. J. Phys. D Appl. Phys. 2018, 51, 203002. [CrossRef]

34. Moonoosawmy, K.R.; Kruse, P. Cause and Consequence of Carbon Nanotube Doping in Water and Aqueous Media. J. Am. Chem. Soc. 2010, 132, 1572-1577. [CrossRef] [PubMed]

35. Fennell, J.F.; Liu, S.F.; Azzarelli, J.M.; Weis, J.G.; Rochat, S.; Mirica, K.A.; Ravnsbaek, J.B.; Swager, T.M. Nanowire Chemical/Biological Sensors: Status and a Roadmap for the Future. Angew. Chem. Int. Ed. 2016, 55, 1266-1281. [CrossRef]

36. Tang, R.; Shi, Y.; Hou, Z.; Wei, L. Carbon Nanotube-Based Chemiresistive Sensors. Sensors 2017, 17, 882. [CrossRef]

37. Lange, U.; Mirsky, V.M. Chemiresistors based on conducting polymers: A review on measurement techniques. Anal. Chim. Acta 2011, 687, 105-113. [CrossRef]

38. Jaffrezic-Renault, N.; Dzyadevych, S.V. Conductometric Microbiosensors for Environmental Monitoring. Sensors 2008, 8, 2569-2588. [CrossRef]

39. Watson, L.D.; Maynard, P.; Cullen, D.C.; Sethi, R.S.; Brettle, J.; Lowe, C.R. A microelectronic conductimetric biosensor. Top. Catal. 1987, 3, 101-115. [CrossRef]

40. Hwa-II, S.; Chang-Soo, K.; Byung-Ki, S.; Terence, Y.; Son Mun-Tak, H.M. ISFET glucose sensor based on a new prinicple using the electrolysis of hydrogen peroixde. Sens. Actuators B Chem. 1997, 40, 1-5.

41. Shul'Ga, A.A.; Gibson, T.D. An alternative microbiosensor for hydrogen peroxide based on an enzyme field effect transistor with a fast response. Anal. Chim. Acta 1994, 296, 163-170. [CrossRef]

42. Sohn, B.-K.; Cho, B.-W.; Kim, C.-S.; Kwon, D.-H. ISFET glucose and sucrose sensors by using platinum electrode and photocrosslinkable polymers. Sens. Actuators B Chem. 1997, 41, 7-11. [CrossRef]

43. Sergeyeva, T.A.; Lavrik, N.V.; Rachkov, A.E.; Kazantseva, Z.I.; Piletsky, S.A.; El'Skaya, A.V. Hydrogen peroxide-Sensitive enzyme sensor based on phthalocyanine thin film. Anal. Chim. Acta 1999, 391, 289-297. [CrossRef]

44. Dam, V.-A.T.; Oithuis, W.; Bergveld, P.; ven den Berg, A. Catalytic Hydrogen Peroxide decompositon on pervoskite oxide. In Proceedings of the 13th International Conference on Solid-State Sensors, Actuators and Microsystems, Seoul, South Korea, 22 August 2005; Volume 2, pp. 1840-1843. [CrossRef]

45. Kim, C.S.; Seo, H.I.; Lee, C.H.; Sohn, B.K. Miniaturized ISFET glucose sensor including a new structure actuation system. In Proceedings of the International Solid State Sensors and Actuators Conference (Transducers ‘97), Chicago, IL, USA, 19 June 1997; Volume 2, pp. 911-914. [CrossRef]

46. Diallo, A.K.; Djeghlaf, L.; Mazenq, L.; Launay, J.; Sant, W.; Temple-Boyer, P. Development of pH-based ElecFET biosensors for lactate ion detection. Biosens. Bioelectron. 2013, 40, 291-296. [CrossRef] [PubMed]

47. Van Der Spiegel, J.; Lauks, I.; Chan, P.; Babic, D. The extended gate chemically sensitive field effect transistor as multi-species microprobe. Sens. Actuators 1983, 4, 291-298. [CrossRef]

48. Teh, K.-S.; Lin, L. MEMS sensor material based on polypyrrole-carbon nanotube nanocomposite: Film deposition and characterization. J. Micromech. Microeng. 2005, 15, 2019-2027. [CrossRef]

49. Salila Vijayalal Mohan, H.K.; Hansen Varghese, R.; Wong, C.H.; Zheng, L.; Yang, J. Epigallocatechin gallate decorated carbon nanotube chemiresistors for ultrasensitive glucose detection. Org. Electron. 2016, 28, 210-216. [CrossRef]

50. Song, E.; Da Costa, T.H.; Choi, J.W. A chemiresistive glucose sensor fabricated by inkjet printing. Microsyst. Technol. 2017, 23, 3505-3511. [CrossRef]

51. Song, E.; Tortorich, R.P.; Da Costa, T.H.; Choi, J.W. Inkjet printing of conductive polymer nanowire network on flexible substrates and its application in chemical sensing. Microelectron. Eng. 2015, 145, 143-148. [CrossRef]

52. Song, E.; Choi, J.W. Multi-analyte detection of chemical species using a conducting polymer nanowire-based sensor array platform. Sens. Actuators B Chem. 2015, 215, 99-106. [CrossRef]

53. Song, E.; Choi, J.W. Self-calibration of a polyaniline nanowire-based chemiresistive pH sensor. Microelectron. Eng. 2014, 116, 26-32. [CrossRef]

54. Ansari, S.G.; Ansari, Z.A.; Wahab, R.; Kim, Y.S.; Khang, G.; Shin, H.S. Glucose sensor based on nano-baskets of tin oxide templated in porous alumina by plasma enhanced CVD. Biosens. Bioelectron. 2008, 23, 1838-1842. [CrossRef] [PubMed]

55. Hnaien, M.; Lagarde, F.; Jaffrezic-Renault, N. A rapid and sensitive alcohol oxidase/catalase conductometric biosensor for alcohol determination. Talanta 2010, 81, 222-227. [CrossRef] [PubMed]

56. Bouyahia, N.; Hamlaoui, M.L.; Hnaien, M.; Lagarde, F.; Jaffrezic-Renault, N. Impedance spectroscopy and conductometric biosensing for probing catalase reaction with cyanide as ligand and inhibitor. Bioelectrochemistry 2011, 80, 155-161. [CrossRef]

57. Nguyen-Boisse, T.T.; Saulnier, J.; Jaffrezic-Renault, N.; Lagarde, F. Highly sensitive conductometric biosensors for total lactate, d- and l-lactate determination in dairy products. Sens. Actuators B Chem. 2013, 179, 232-239. [CrossRef]

58. Liu, H.; Yang, Y.; Chen, P.; Zhong, Z. Enhanced conductometric immunoassay for hepatitis B surface antigen using double-codified nanogold particles as labels. Biochem. Eng. J. 2009, 45, 107-112. [CrossRef]

59. Mahadeva, S.K.; Kim, J. Conductometric glucose biosensor made with cellulose and tin oxide hybrid nanocomposite. Sens. Actuators B Chem. 2011, 157, 177-182. [CrossRef] 
60. Volotovsky, V.; Kim, N. Cyanide determination by an ISFET-based peroxidase biosensor. Biosens. Bioelectron. 1998, 13, 1029-1033. [CrossRef]

61. Forzani, E.S.; Zhang, H.; Nagahara, L.A.; Amlani, I.; Tsui, R.; Tao, N. A Conducting Polymer Nanojunction Sensor for Glucose Detection. Nano Lett. 2004, 4, 1785-1788. [CrossRef]

62. Luo, X.L.; Xu, J.J.; Zhao, W.; Chen, H.Y. A novel glucose ENFET based on the special reactivity of $\mathrm{MnO}_{2}$ nanoparticles. Biosens. Bioelectron. 2004, 19, 1295-1300. [CrossRef]

63. Bernards, D.A.; Macaya, D.J.; Nikolou, M.; DeFranco, J.A.; Takamatsu, S.; Malliaras, G.G. Enzymatic sensing with organic electrochemical transistors. J. Mater. Chem. 2008, 18, 116-120. [CrossRef]

64. Liu, J.; Agarwal, M.; Varahramyan, K. Glucose sensor based on organic thin film transistor using glucose oxidase and conducting polymer. Sens. Actuators B Chem. 2008, 135, 195-199. [CrossRef]

65. Yoon, H.; Ko, S.; Jang, J. Field-Effect-Transistor Sensor Based on Enzyme-Functionalized Polypyrrole Nanotubes for Glucose Detection. J. Phys. Chem. B 2008, 112, 9992-9997. [CrossRef] [PubMed]

66. Park, J.W.; Park, S.J.; Kwon, O.S.; Lee, C.; Jang, J. Polypyrrole Nanotube Embedded Reduced Graphene Oxide Transducer for Field-Effect Transistor-Type H2O2 Biosensor. Anal. Chem. 2014, 86, 1822-1828. [CrossRef] [PubMed]

67. Park, J.W.; Lee, C.; Jang, J. High-performance field-effect transistor-type glucose biosensor based on nanohybrids of carboxylated polypyrrole nanotube wrapped graphene sheet transducer. Sens. Actuators B Chem. 2015, 208, 532-537. [CrossRef]

68. Yin, L.T.; Chou, J.C.; Chung, W.Y.; Sun, T.P.; Hsiung, K.P.; Hsiung, S.K. Glucose ENFET doped with MnO 2 powder. Sens. Actuators B Chem. 2001, 76, 187-192. [CrossRef]

69. Anh, D.T.V.; Olthuis, W.; Bergveld, P. Electroactive gate materials for a hydrogen peroxide sensitive eMOSFET. IEEE Sens. J. 2002, 2, 26-33. [CrossRef]

70. Lin, J.J.; Wu, Y.L.; Hsu, P.Y. Novel Dry-Type Glucose Sensor Based on a Metal-Oxide-Semiconductor Capacitor Structure with Horseradish Peroxidase + Glucose Oxidase Catalyzing Layer. Jpn. J. Appl. Phys. Part 1 Regul. Pap. Short Notes Rev. Pap. 2007, 46, 6871-6874. [CrossRef]

71. Ozasa, K.; Nemoto, S.; Li, Y.; Hara, M.; Maeda, M.; Mochitate, K. Contact angle and biocompatibility of sol-gel prepared TiO2 thin films for their use as semiconductor-based cell-viability sensors. Surf. Interface Anal. 2008, 40, 579-583. [CrossRef]

72. Chen, Y.; Lee, Y.D.; Vedala, H.; Allen, B.L.; Star, A. Exploring the Chemical Sensitivity of a Carbon Nanotube/Green Tea Composite. ACS Nano 2010, 4, 6854-6862. [CrossRef]

73. Wu, Y.L.; Hsu, P.Y.; Lin, J.J. Polysilicon wire glucose sensor highly immune to interference. Biosens. Bioelectron. 2011, 26, 2281-2286. [CrossRef] [PubMed]

74. Ahmad, R.; Tripathy, N.; Park, J.H.; Hahn, Y.B. A comprehensive biosensor integrated with a ZnO nanorod FET array for selective detection of glucose, cholesterol and urea. Chem. Commun. 2015, 51, 11968-11971. [CrossRef] [PubMed]

75. Bartlett, P.N.; Birkin, P.R.; Wang, J.H.; Palmisano, F.; De Benedetto, G. An Enzyme Switch Employing Direct Electrochemical Communication between Horseradish Peroxidase and a Poly(aniline) Film. Anal. Chem. 1998, 70, 3685-3694. [CrossRef] [PubMed]

76. Raffa, D.; Leung, K.T.; Battaglini, F. A Microelectrochemical Enzyme Transistor Based on an N-Alkylated Poly(Aniline) and Its Application to Determine Hydrogen Peroxide at Neutral pH. Anal. Chem. 2003, 75, 4983-4987. [CrossRef]

77. Huang, Y.; Dong, X.; Shi, Y.; Li, C.M.; Li, L.J.; Chen, P. Nanoelectronic biosensors based on CVD grown graphene. Nanoscale 2010, 2, 1485-1488. [CrossRef]

78. Kwak, Y.H.; Choi, D.S.; Kim, Y.N.; Kim, H.; Yoon, D.H.; Ahn, S.S.; Yang, J.W.; Yang, W.S.; Seo, S. Flexible glucose sensor using CVD-grown graphene-based field effect transistor. Biosens. Bioelectron. 2012, 37, 82-87. [CrossRef]

79. You, X.; Pak, J.J. Graphene-based field effect transistor enzymatic glucose biosensor using silk protein for enzyme immobilization and device substrate. Sens. Actuators B Chem. 2014, 202, 1357-1365. [CrossRef]

80. Van Der Schoot, B.H.; Bergveld, P. ISFET based enzyme sensors. Biosensors 1987, 3, 161-186. [CrossRef]

81. Lee, C.H.; Seo, H.I.; Lee, Y.C.; Cho, B.W.; Jeong, H.; Sohn, B.K. All solid type ISFET glucose sensor with fast response and high sensitivity characteristics. Sens. Actuators B Chem. 2000, 64, 37-41. [CrossRef]

82. Zhang, Q.; Kaisti, M.; Prabhu, A.; Yu, Y.; Song, Y.A.; Rafailovich, M.H.; Rahman, A.; Levon, K. Polyaniline-functionalized ion-sensitive floating-gate FETs for the on-chip monitoring of peroxidase-catalyzed redox reactions. Electrochim. Acta 2018, 261, 256-264. [CrossRef]

83. Zhu, Z.; Mabeck, J.T.; Zhu, C.; Cady, N.C.; Batt, A.; Malliaras, G.G. A simple PEDOT:PSS transistor for glucose sensing at neutral pH. Chem. Commun. 2004, 13, 1556-1557. [CrossRef] [PubMed]

84. Kim, Y.; Do, J.; Kim, J.; Yang, S.Y.; Malliaras, G.G.; Ober, C.K.; Kim, E. A Glucose Sensor Based on an Organic Electrochemical Transistor Structure Using a Vapor Polymerized Poly(3,4-ethylenedioxythiophene) Layer. Jpn. J. Appl. Phys. 2010, 49. [CrossRef]

85. Liao, J.; Lin, S.; Yang, Y.; Liu, K.; Du, W. Highly selective and sensitive glucose sensors based on organic electrochemical transistors using TiO2 nanotube arrays-based gate electrodes. Sens. Actuators B Chem. 2015, 208, 457-463. [CrossRef]

86. Welch, M.E.; Doublet, T.; Bernard, C.; Malliaras, G.G.; Ober, C.K. A glucose sensor via stable immobilization of the GOx enzyme on an organic transistor using a polymer brush. J. Polym. Sci. Part A Polym. Chem. 2015, 53, 372-377. [CrossRef]

87. Macdiarmid, A.G.; Epstein, A.J. The Polyanilines: A Novel Class of Conducting Polymers. MRS Proc. 1989, 173. [CrossRef]

88. Ray, A.; Asturias, G.E.; Kershner, D.L.; Richter, A.F.; MacDiarmid, A.G.; Epstein, A.J. Polyaniline: Doping, structure and derivatives. Synth. Met. 1989, 29, 141-150. [CrossRef] 
89. Bartlett, P.N.; Wang, J.H. Electroactivity, stability and application in an enzyme switch at pH 7 of poly(aniline)-poly(styrenesulfonate) composite films. J. Chem. Soc. Faraday Trans. 1996, 92, 4137-4143. [CrossRef]

90. Song, E.; Choi, J.-W. Conducting Polyaniline Nanowire and Its Applications in Chemiresistive Sensing. Nanomaterials 2013, 3, 498-523. [CrossRef]

91. Keiji Kanazawa, K.; Diaz, A.F.; Gill, W.D.; Grant, P.M.; Street, G.B.; Piero Gardini, G.; Kwak, J.F. Polypyrrole: An electrochemically synthesized conducting organic polymer. Synth. Met. 1980, 1, 329-336. [CrossRef]

92. Lu, J.; Pinto, N.J.; MacDiarmid, A.G. Apparent dependence of conductivity of a conducting polymer on an electric field in a field effect transistor configuration. J. Appl. Phys. 2002, 92, 6033-6038. [CrossRef]

93. Nilsson, B.D.; Chen, M.; Kugler, T.; Remonen, T.; Armgarth, M.; Berggren, M. Bi-stable and Dynamic Current Modulation in Electrochemical Organic Transistors. Adv. Mater. 2002, 14, 51-54. [CrossRef]

94. Jung, D.-U.-J.; Ahmad, R.; Hahn, Y.B. Nonenzymatic flexible field-effect transistor based glucose sensor fabricated using NiO quantum dots modified ZnO nanorods. J. Colloid Interface Sci. 2018, 512, 21-28. [CrossRef] [PubMed]

95. Zheng, X.; Guo, Z. Potentiometric determination of hydrogen peroxide at MnO2-doped carbon paste electrode. Talanta 2000, 50, 1157-1162. [CrossRef]

96. Manso, M.; Ogueta, S.; García, P.; Pérez-Rigueiro, J.; Jiménez, C.; Martínez-Duart, J.M.; Langlet, M. Mechanical and in vitro testing of aerosol-gel deposited titania coatings for biocompatible applications. Biomaterials 2002, 23, 349-356. [CrossRef]

97. Tang, H.; Yan, F.; Lin, P.; Xu, J.; Chan, H.L.W. Highly Sensitive Glucose Biosensors Based on Organic Electrochemical Transistors Using Platinum Gate Electrodes Modified with Enzyme and Nanomaterials. Adv. Funct. Mater. 2011, 21, 2264-2272. [CrossRef]

98. Liao, C.; Zhang, M.; Niu, L.; Zheng, Z.; Yan, F. Highly selective and sensitive glucose sensors based on organic electrochemical transistors with graphene-modified gate electrodes. J. Mater. Chem. B 2013, 1, 3820-3829. [CrossRef]

99. Zhang, M.; Liao, C.; Mak, C.H.; You, P.; Mak, C.L.; Yan, F. Highly sensitive glucose sensors based on enzyme-modified whole-graphene solution-gated transistors. Sci. Rep. 2015, 5, 1-6. [CrossRef]

100. Allen, B.L.; Kichambare, P.D.; Star, A. Carbon Nanotube Field-Effect-Transistor-Based Biosensors. Adv. Mater. 2007, 19, 1439-1451. [CrossRef]

101. Liu, S.; Guo, X. Carbon nanomaterials field-effect-transistor-based biosensors. NPG Asia Mater. 2012, 4, 1-10. [CrossRef]

102. Tran, T.T.; Mulchandani, A. Carbon nanotubes and graphene nano field-effect transistor-based biosensors. TrAC Trends Anal. Chem. 2016, 79, 222-232. [CrossRef]

103. Wang, C.; Takei, K.; Takahashi, T.; Javey, A. Carbon nanotube electronics-Moving forward. Chem. Soc. Rev. 2013, 42, 2592-2609. [CrossRef] [PubMed]

104. Nakamura, G.; Narimatsu, K.; Niidome, Y.; Nakashima, N. Green Tea Solution Individually Solubilizes Single-walled Carbon Nanotubes. Chem. Lett. 2007, 36, 1140-1141. [CrossRef]

105. Schulman, D.S.; Arnold, A.J.; Das, S. Contact engineering for 2D materials and devices. Chem. Soc. Rev. 2018, 47, 3037-3058. [CrossRef] [PubMed]

106. Das, S.; Chen, H.Y.; Penumatcha, A.V.; Appenzeller, J. High Performance Multilayer MoS2 Transistors with Scandium Contacts. Nano Lett. 2013, 13, 100-105. [CrossRef]

107. Jiang, C.; Wang, G.; Hein, R.; Liu, N.; Luo, X.; Davis, J.J. Antifouling Strategies for Selective In Vitro and In Vivo Sensing. Chem. Rev. 2020, 120, 3852-3889. [CrossRef] 